science for a changing world

Prepared in cooperation with the Afghan Geological Survey under the auspices of the U.S. Department of Defense Task Force for Business and Stability Operations

\title{
Assessment of Bauxite, Clay, and Laterite Deposits in Afghanistan
}

Open-File Report 2014-1210

USGS Afghanistan Project Product No. 197

U.S. Department of the Interior

U.S. Geological Survey 



\section{Assessment of Bauxite, Clay, and Laterite Deposits in Afghanistan}

By Karine M. Renaud, Bruce R. Wardlaw, and Bernard E. Hubbard

Prepared in cooperation with the Afghan Geological Survey under the auspices of the U.S. Department of Defense Task Force for Business and Stability Operations

Open-File Report 2014-1210

USGS Afghanistan Project Product No. 197 


\title{
U.S. Department of the Interior SALLY JEWELL, Secretary
}

\section{U.S. Geological Survey Suzette M. Kimball, Acting Director}

\author{
U.S. Geological Survey, Reston, Virginia: 2015
}

For more information on the USGS - the Federal source for science about the Earth, its natural and living resources, natural hazards, and the environment—visit http://www.usgs.gov or call 1-888-ASK-USGS.

For an overview of USGS information products, including maps, imagery, and publications, visit http://www.usgs.gov/pubprod

To order this and other USGS information products, visit http://store.usgs.gov

Any use of trade, firm, or product names is for descriptive purposes only and does not imply endorsement by the U.S. Government.

Although this information product, for the most part, is in the public domain, it also may contain copyrighted materials as noted in the text. Permission to reproduce copyrighted items must be secured from the copyright owner.

Suggested citation:

Renaud, K.M., Wardlaw, B.R., and Hubbard, B.E., 2015, Assessment of bauxite, clay, and laterite deposits in Afghanistan: U.S. Geological Survey Open-File Report 2014-1210, 40 p., http://dx.doi.org/10.3133/ofr20141210.

ISSN 2331-1258 (Online) 


\section{Contents}

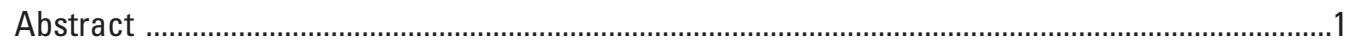

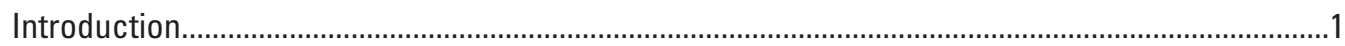

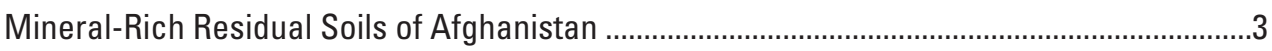

Bauxite Occurrences and Deposits in Afghanistan..................................................................

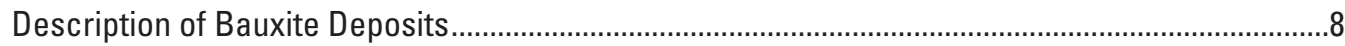

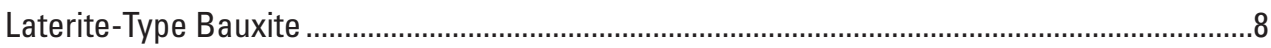

The Laterite-Type Bauxite Complete Profile.......................................................................8

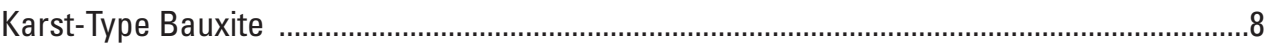

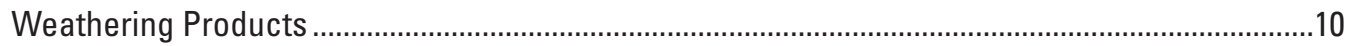

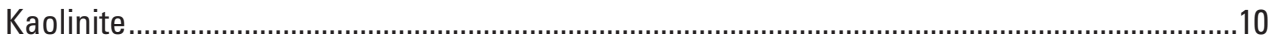

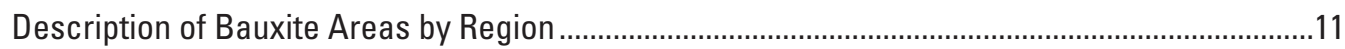

Afghanistan-South Pamir Folded Region (Herat (Hirat)-Ghor)...............................................11

Haftqala, Rode Kafghan, Khwaja Morad and Qarghanaw Zones....................................11

Kohe-Safed I and II Bauxite Occurrences ............................................................14

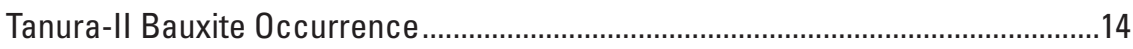

Dagane-Doi Bauxite Deposit ..................................................................................14

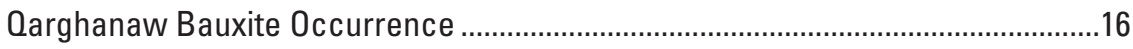

Afghanistan-North Pamir Folded Region (Badakshan) ............................................................17

Faydz Abad and Safed Hers Bauxite Zones ...................................................................17

Shewa Bauxite Occurrence................................................................................17

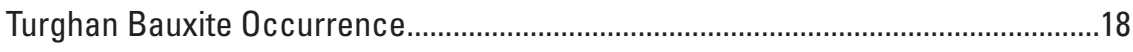

South Afghanistan Region (Kandahar, Zabul, Ghazni, and Uruzgan) .....................................18

Ghazni (Ganzi) Province, Arghandab Block ...............................................................19

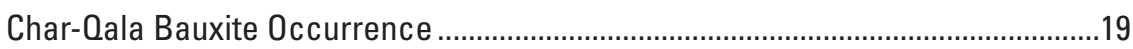

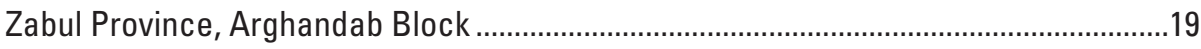

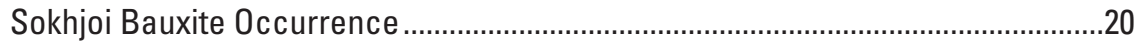

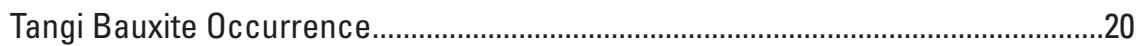

Kandahar Province, Arghandab and Tirin Blocks ..........................................................22

Obatu Sheila Bauxite Deposit............................................................................24

Tor Ghar Bauxite Deposit...........................................................................................

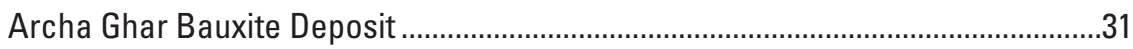

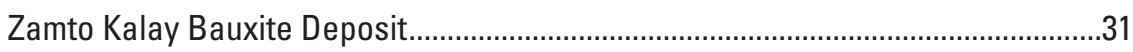

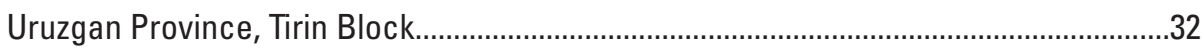

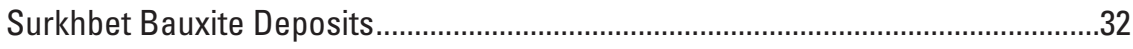

Doubalagh Bauxite Deposit ...................................................................................

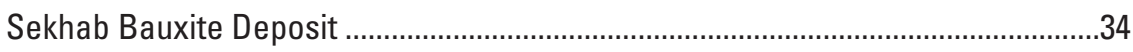

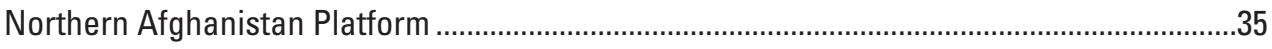

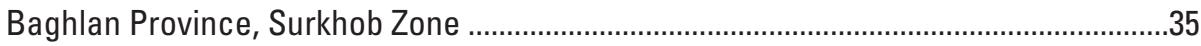

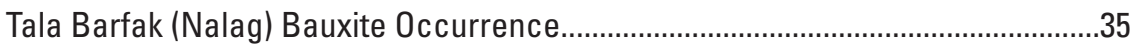

Estoma Bauxite Occurrence ...................................................................................36

Eshpushta Bauxite Occurrence ...........................................................................

Summary

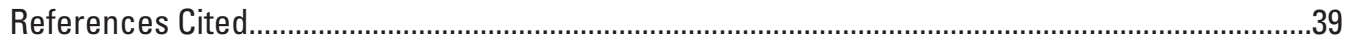




\section{Figures}

1. Maps showing migration of the Cimmerian arc that assembled to form much of Afghanistan .............................................................................................................

2. Map of bauxite deposits and occurrences based on tectonic zones ..............................

3. Map of bauxite deposits and occurrences based on map units ......................................

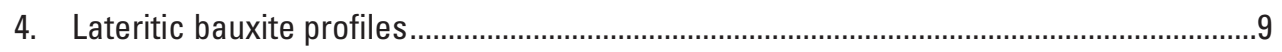

5. Karst-type bauxite profile .................................................................................................

6. Location of bauxite occurrences in Haftqala, Rode Kafghan, Khwaja Morad and Oarghanaw zones, Herat (Hirat) and Ghor Provinces ..............................................11

7. Stratigraphic column, Haftqala zone in Herat (Hirat) and Ghor Provinces.......................13

8. Section of Permian deposits in Shewa River Valley.......................................................18

9. Sokhjoi bauxite occurrence, Arghandab block, Zabul Province, aerial

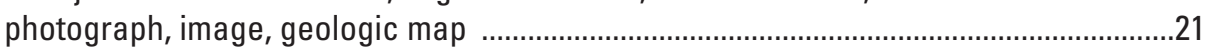

10. Correlation of Vargach Formation in the Tirin block, Kandahar Province.........................23

11. Structural map of the Obatu Sheila bauxite deposit.........................................................24

12. Schematic geologic map of Obatu Sheila II exposed ore, Kandahar Province ...............25

13. Map of ore-reserves calculation for the Obatu Sheila bauxite deposit in

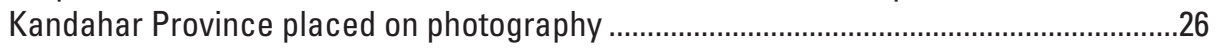

14. Location of Kandahar Bauxite Area and subareas in Kandahar, Uruzgan,

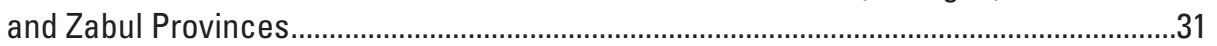

15. Profile of section of Surkhbet bauxite deposit in Uruzgan Province ...............................32

16. Correlation of Vargach Formation for Surkhbet deposits in Kandahar Province ............33

17. Detailed profile of Surkhbet and Doubalagh.................................................................

18. Schematic geologic map of the Estoma bauxite occurrence ..........................................37

\section{Tables}

1. Chemical compositions associated with various industrial grades of bauxite....................

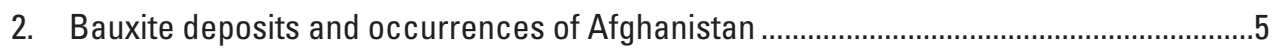

3. Results of chemical analysis of the Kohe-Safed bauxite occurrence ............................14

4. Geochemical results for the Tanura-II bauxite occurrences...........................................14

5. Geochemical results of samples from the Dagane-Doi bauxite occurrences .................14

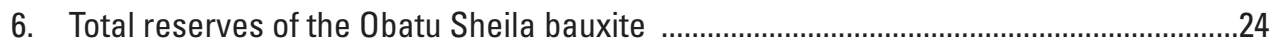

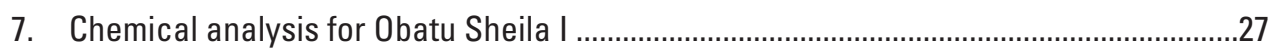

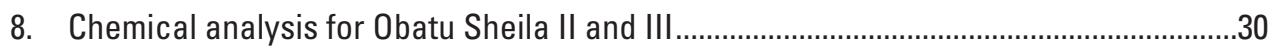

9. Analysis of three samples from the Surkhbet bauxite deposit ........................................33

10. Geochemical results from Estoma bauxite occurrence ................................................36

11. Summary characteristics of selected bauxite occurrences and deposits in Afghanistan 


\section{Conversion Factors}

\begin{tabular}{lll}
\hline \multicolumn{1}{c}{ Multiply } & By & \multicolumn{1}{c}{ To obtain } \\
\hline centimeter $(\mathrm{cm})$ & Length & inch (in.) \\
millimeter $(\mathrm{mm})$ & 0.3937 & inch (in.) \\
meter $(\mathrm{m})$ & 0.03937 & foot (ft) \\
meter $(\mathrm{m})$ & 3.281 & yard (yd) \\
kilometer $(\mathrm{km})$ & 1.094 & mile (mi) \\
\hline & 0.6214 & acre \\
\hline square kilometer $\left(\mathrm{km}^{2}\right)$ & Area & square mile (mi $\left.{ }^{2}\right)$ \\
square kilometer $\left(\mathrm{km}^{2}\right)$ & 247.1 & \\
\hline & 0.3861 & ton, short (ton) \\
\hline metric ton (tonne) & Mass & \\
\hline
\end{tabular}

Results of chemical analyses are given in weight percent (wt \%) and volume percent (vol \%).

\section{Datum}

Horizontal coordinate information is referenced to the World Geodetic System of 1984 (WGS 84). 



\title{
Assessment of Bauxite, Clay, and Laterite Deposits in Afghanistan
}

\author{
By Karine M. Renaud, Bruce R. Wardlaw, and Bernard E. Hubbard
}

\section{Abstract}

Bauxite-bearing rocks are present in several regions of Afghanistan; specifically, the southeast segment of the North Afghanistan Platform, the eastern parts of South Afghanistan, and within the Afghanistan-North and -South Pamir Fold Regions. Bauxite-bearing rocks occur at various stratigraphic levels, in lithologically different sequences of sedimentary rocks. The bauxites are paleosols and represent previous, rather than recent, weathering events. Bauxites and bauxite-type horizons are most common at the base of carbonate rock units, where they form the basal horizons of sedimentary rock sequences separated by erosion and stratigraphic unconformity surfaces. Less common are zones in redeposited weathering developed on igneous rocks. At present there are five known stratigraphic intervals with significant bauxite and bauxite-type deposits and occurrences: the lower Permian, the upper Permian, the Upper Triassic, the Lower Jurassic, and the base of the Upper Jurassic.

This report summarizes a compilation and review of geological data for regions in Afghanistan that contain bauxite deposits and occurrences based on work conducted during 2009 to 2011 by the U.S. Geological Survey, the U.S. Department of Defense Task Force for Business and Stability Operations, and the Afghanistan Geological Survey.

Permian strata contain bauxites and bauxite-like rocks that are recognizable at various stratigraphic intervals within several areas of southern Afghanistan and in the Central Afghan Massif in central Afghanistan. The main zones of known bauxite occurrences are the Haftqala bauxite zone (late Permian and Late Triassic), Shewa bauxite zone (early Permian), Qarghanaw bauxite zone (late Permian and Late Triassic), Arghandab block in Zabul Province (middle through late Permian), Arghandab block in Ghazni Province (early Permian), Surkhob bauxite zone (Early Jurassic), and Tirin block in Uruzgan, Zabul, and Kandahar Provinces (Late Jurassic).

Although some bauxite occurrences were sampled in the course of reconnaissance exploration by Soviet workers in the 1960s and 1970s, the bauxite areas in Afghanistan generally are underexplored. The Obatu Sheila area is a known field of bauxite deposits of Late Jurassic age that had been studied in more detail than other known bauxite deposits and occurrences in Afghanistan. Obatu Sheila has an estimated reserve of 7.2 million tons.

\section{Introduction}

The material summarized in this report is the archival data for bauxite-bearing rock, located in several areas of Afghanistan (fig. 1) and identified by Soviet geologists in the 1960s and 1970s. Aluminum is the third most abundant element in the Earth's crust after oxygen and silicon. It is an important constituent in all clays and soil and of the silicates of common rocks (Jensen and Bateman, 1981). It occurs in nature combined with other elements mostly in silicate minerals, from which it is difficult and expensive to extract.

Bauxite, an ore of aluminum, is a complex and impure mixture of aluminum minerals, chiefly aluminum hydroxides (Patterson and Dyni, 1973). Bauxite is not a product of normal weathering in temperate regions (Jensen and Bateman, 1981). It forms in tropical and subtropical regions as a constituent of lateritic soils. Bauxite is an accumulated product of weathering of aluminum silicate rocks lacking much free quartz. The silicates are broken down, the silica is removed, iron is partly removed, water is added, and aluminum, titanium, and ferric oxide and perhaps manganese oxide become concentrated in the residue (Jensen and Bateman, 1981). The more silica removed, or the more leachable the rock in the deposit, the greater the chance that 

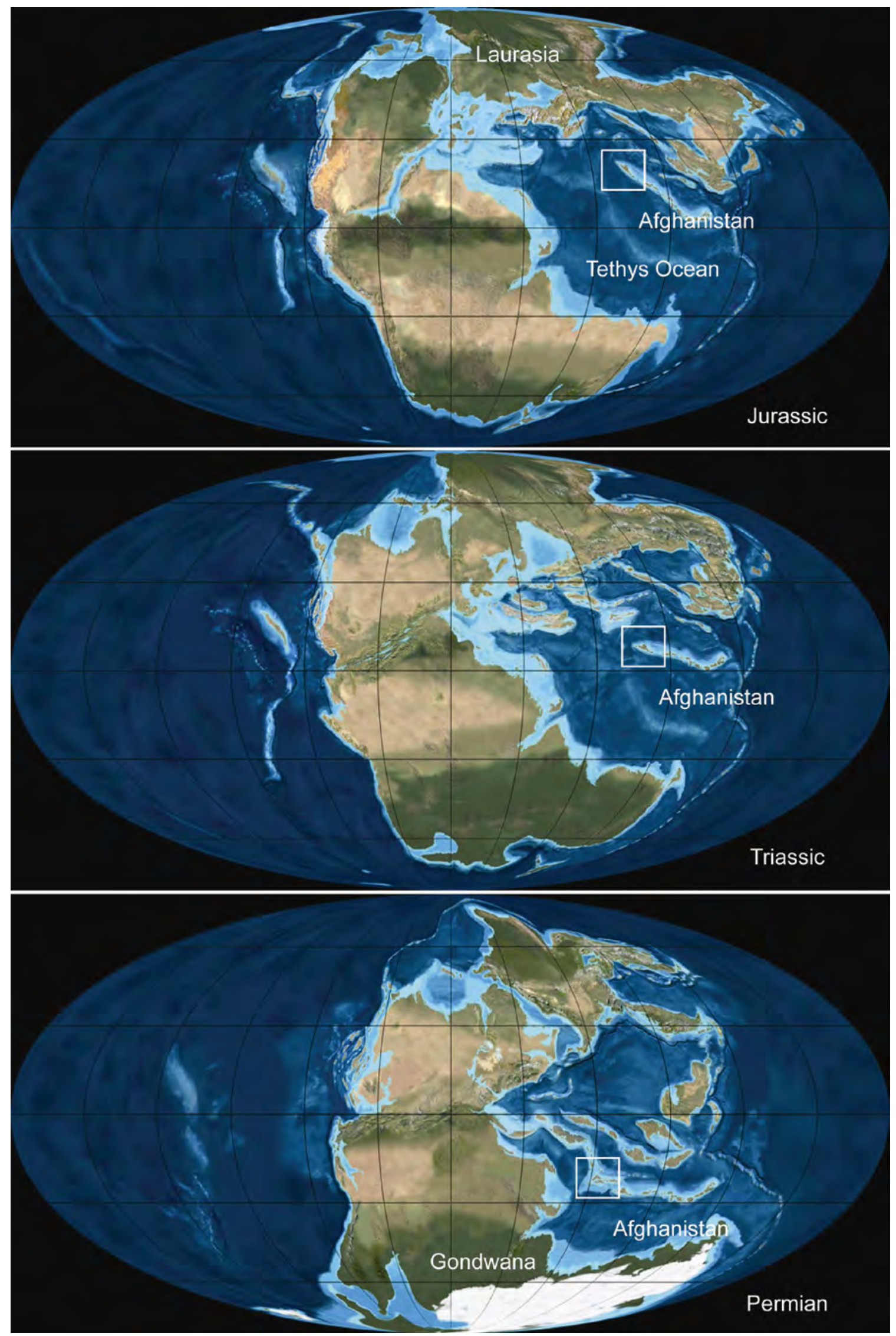

Figure 1. Maps showing migration of the Cimmerian arc that assembled to form much of Afghanistan (modified from Blakey, 2011). 
the deposit will be enriched in aluminum rather than iron. Gibbsite, boehmite, and diaspore are the principal minerals in bauxite. Bauxites are important for production of high-quality abrasives, ceramics, and chemical and refractory products (table 1) (Patterson, 1984).

Table 1. Chemical compositions associated with various industrial grades of bauxite.

$[$ - no data $]$

\begin{tabular}{lcccc}
\hline \multirow{2}{*}{ Grade } & \multicolumn{4}{c}{ Content, in weight percent } \\
\cline { 2 - 5 } & $\mathbf{A l}_{\mathbf{2}} \mathbf{O}_{\mathbf{3}}$ & $\mathbf{S i O}_{\mathbf{2}}$ & $\mathbf{F e}_{\mathbf{2}} \mathbf{O}_{\mathbf{3}}$ & $\mathbf{T i O}_{\mathbf{2}}$ \\
\hline Metallurgical & $50-55$ & $0-15$ & $5-30$ & - \\
Abrasive & Minimum 55 & Maximum 5 & Maximum 6 & Minimum 2.5 \\
Chemical & Minimum 55-58 & Maximum 5-12 & Maximum 2 & - \\
Refractory & Minimum 59-61 & Maximum 1.5-5.5 & Maximum 2 & Maximum 2.5 \\
\hline
\end{tabular}

\section{Mineral-Rich Residual Soils of Afghanistan}

A residual soil is a concentration of insoluble material that remains after the soluble material is dissolved and removed. There are at least three residual soils that can be of economic value: clays (kaolinite), iron-rich laterite, and bauxite (aluminum ore). In addition, weathering of mineral deposits containing copper, gold, and zinc may also enrich the mineralized areas, making them more metallurgically viable and therefore economically viable. Most important residual soils are formed under tropical, tectonically stable conditions because high rainfall is needed for the intense weathering required to develop clays laterite and bauxite or to develop the solutions that dissolve and remove mineral matter. Afghanistan is far from tropical or tectonically stable today, but much of what is now Afghanistan was in the tropical or subtropical belt from the Permian through the Jurassic (299.0-145.0 Ma). What makes up much of Afghanistan today were parts of the Cimmerian plate (or arc) that broke off from Gondwana by rifting in the Permian and migrated across the Tethys ocean (an ancient tropical ocean) to collide with Laurasia (Eurasia) in the Jurassic (fig. 1). So, the conditions were favorable for development of economic residual soils during this timespan.

\section{Bauxite Occurrences and Deposits in Afghanistan}

As mentioned previously, bauxite is an aluminum ore consisting of the aluminum oxide or hydroxide minerals gibbsite, boehmite, and diaspore that are commonly mixed with the iron oxides goethite and hematite, and with the clay mineral kaolinite. The economic ores of aluminum generally contain more than 45 to 50 weight percent (wt \%) alumina $\left(\mathrm{Al}_{2} \mathrm{O}_{3}\right)$, not more than 20 wt $\%$ ferric oxide $\left(\mathrm{Fe}_{2} \mathrm{O}_{3}\right)$, and 3 to $5 \mathrm{wt} \%$ silica $\left(\mathrm{SiO}_{2}\right)$ (Patterson, 1984).

Two basic types of bauxite deposits that are known in Afghanistan are the laterite and karst types. Favorable weathering conditions that produce deposits enriched in iron (laterites) and alumina (karst) include (1) humid tropical or subtropical climate, (2) rocks high in aluminum in a form susceptible to yielding bauxite, (3) available reagents, including precipitation, to promote the chemical weathering of the silicates and solution of silica at specific $\mathrm{pH}$ and Eh conditions, (4) stable surfaces that permit a slow downward infiltration of meteoric water, (5) subsurface conditions that allow the removal of dissolved products, (6) long periods of tectonic stability, and (7) preservation of the deposits (Jensen and Bateman, 1981). 
Bauxite has been identified in four major structural regions of Afghanistan: (1) the Afghanistan-South Pamir folded region, (2) the Afghanistan-North Pamir folded region, (3) the North Afghanistan platform, and (4) the South Afghanistan region (Dovgal and others, 1971). The structural regions are divided by structural features and represent large fault blocks (Chmyriov and others, 1977). Zones identified with bauxite in the Afghanistan-South Pamir folded region are Haftqala, Rode Kafghan, Khwaja Morad, Safed Hers and Qarghanaw. Zones identified with bauxite in the Afghanistan-North Pamir folded region are Faydz Abad and Safed Hers (fig. 2 and table 2). A zone with bauxite in the North Afghanistan platform is Surkhab (fig. 2 and table 2). Structural regions identified with bauxite in the South Afghanistan region are the Tirin and Arghandab blocks (fig. 2 and table 2). Hereafter in this report, distinction is made between an "occurrence" (a concentration of a mineral that is considered valuable by someone somewhere, or that is of scientific and technical interest) and a "deposit" (an occurrence of sufficient size and grade that it might, under the most favorable of circumstances, be considered to have economic potential), consistent with definitions used in U.S. Geological Survey mineral deposit models (Cox and Singer, 1986).

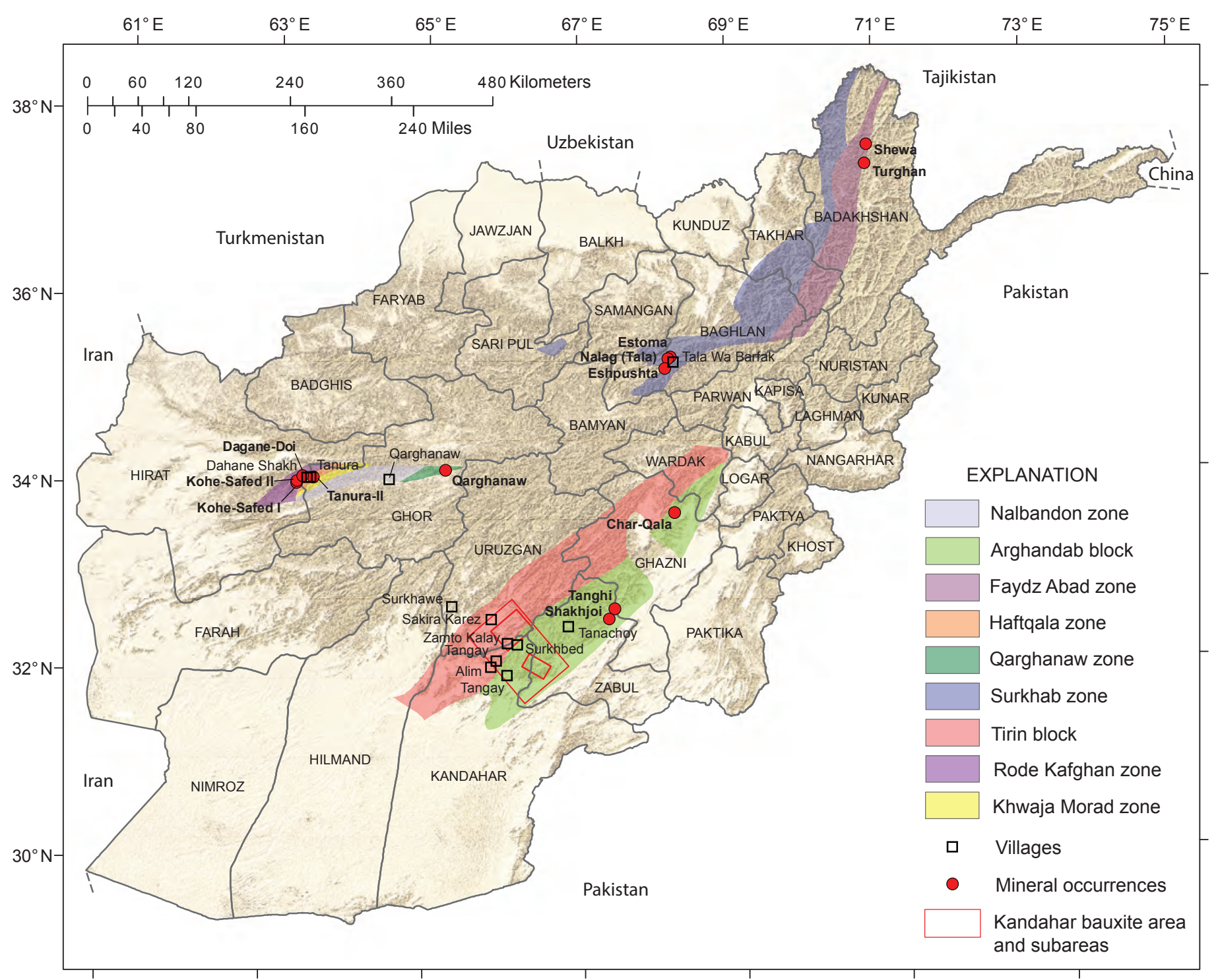

Figure 2. Map of bauxite deposits and occurrences based on tectonic zones (Dovgal and others, 1971). 
Table 2. Bauxite deposits and occurrences of Afghanistan.

\begin{tabular}{|c|c|c|c|c|c|}
\hline Main occurrence & Bauxite zone & Host rock age & Province & Structural region & References \\
\hline $\begin{array}{l}\text { Kohe-Safed, Kohe Pud, } \\
\text { Tanura-II, Dagane-Doi }\end{array}$ & $\begin{array}{l}\text { Haftqala } \\
\text { (Haftkala) }\end{array}$ & $\begin{array}{l}\text { Late Permian } \\
\text { and Late Triassic }\end{array}$ & $\begin{array}{l}\text { Ghor } \\
\text { Herat (Hirat) }\end{array}$ & $\begin{array}{l}\text { Afghanistan-South } \\
\text { folded Pamir }\end{array}$ & $\begin{array}{c}\text { Dronov and others (1970, } \\
\text { 1973, 1976), Dronov } \\
\text { (1980), Leven (1997) }\end{array}$ \\
\hline Qarghanaw (Mene Bum) & Qarghanaw & $\begin{array}{c}\text { Late Permian and } \\
\text { Late Triassic }\end{array}$ & Ghor (Nalbandon) & $\begin{array}{l}\text { Afghanistan-South } \\
\text { folded Pamir }\end{array}$ & Dronov and others (1973) \\
\hline $\begin{array}{l}\text { Tala Barfak (Nalag), } \\
\text { Estoma, Eshpushta }\end{array}$ & Surkhob & Early Jurassic & Baghlan & $\begin{array}{l}\text { North Afghanistan } \\
\text { Platform }\end{array}$ & $\begin{array}{l}\text { Chmyroiy and others } \\
\text { (1977) }\end{array}$ \\
\hline Sokhjoi, Tangi & Arghandab & $\begin{array}{l}\text { Middle-Late } \\
\text { Permian }\end{array}$ & Zabul & South Afghanistan & $\begin{array}{l}\text { Dovgal and others (1971) } \\
\text { Karapetov and others } \\
\text { (1970), Mikhailov and } \\
\text { others (1969) }\end{array}$ \\
\hline Char-Qala & Arghandab & Early Permian & Ghazni (Gazni) & South Afghanistan & $\begin{array}{l}\text { Karapetov and others } \\
\text { (1970) }\end{array}$ \\
\hline $\begin{array}{l}\text { Surkhbet I, II, Tor Ghar, } \\
\text { Doubalagh, Sekhab }\end{array}$ & Tirin & Late Jurassic & $\begin{array}{l}\text { Khandahar, } \\
\text { Uruzghan }\end{array}$ & South Afghanistan & Dovgal and others (1971) \\
\hline $\begin{array}{l}\text { Zamto Kalay, Obatu } \\
\text { Sheila, Archa Ghar }\end{array}$ & Arghandab & Late Jurassic & $\begin{array}{l}\text { Kandahar, } \\
\text { Zabul }\end{array}$ & South Afghanistan & Dovgal and others (1971) \\
\hline
\end{tabular}


Bauxite and bauxitic rocks occur as soils that are developed on an exposure and erosional surface. They are most commonly developed on and are overlain by marine carbonate rock units. The erosional surface appears to represent a maximum regression, and the soil represents initiation of a transgressive system tract. Five stratigraphic levels are notable for the presence of bauxite and bauxitic beds: the lower Permian, the upper Permian, the Upper Triassic, the base of the Jurassic, and the lower part of the Upper Jurassic.

1. Bauxite beds of early Permian age (such as the Char-Qala occurrence in Ghazni (Gazni) Province) overlie Carboniferous rocks and occur at the base of a thick sequence of limestone and dolomite that starts in the Artinskian (middle early Permian) and extends to the late Permian in age (fig. 3).

2. The upper Permian bauxites (such as the Kohe-Safed occurrence in Ghor Province) occur as lenses on top of a thickbedded white limestone and are overlain by an upper Permian (Pamirian) limestone unit, Late Devonian-Mississippian and Permian-undifferentiated.

3. Several exposed surfaces in the Late Triassic have locally developed bauxitic soils, such as the Estoma and Eshpushta, and in Permian Undifferentiated and late Permian, Tanura village and Qarghanaw occurrences (fig. 3).

4. The bauxite-bearing rocks at the base of the Jurassic in northern Afghanistan are notable because they occur on volcanic rocks followed by Jurassic carbonate deposition (Tala Barfak occurrence in Baghlan Province). The bauxite forms tabular bodies in a weathering crust developed over Upper Triassic basalts (Leven, 1976) (fig. 3).

Bauxite occurrences of Upper Jurassic age are known from five localities near Kandahar. Most thoroughly studied of these five occurrences is the Obatu Sheila occurrence, where the bauxite-bearing rocks are present at the base of the Vargach Formation (Jurassic to Cretaceous) of terrigenous-carbonate rocks that transgressively overlie Middle through Upper Jurassic limestone of the Paynawa Limestone. This basal horizon of bauxite-bearing rocks in the Vargach Formation is traceable within an area of several tens of square kilometers. 


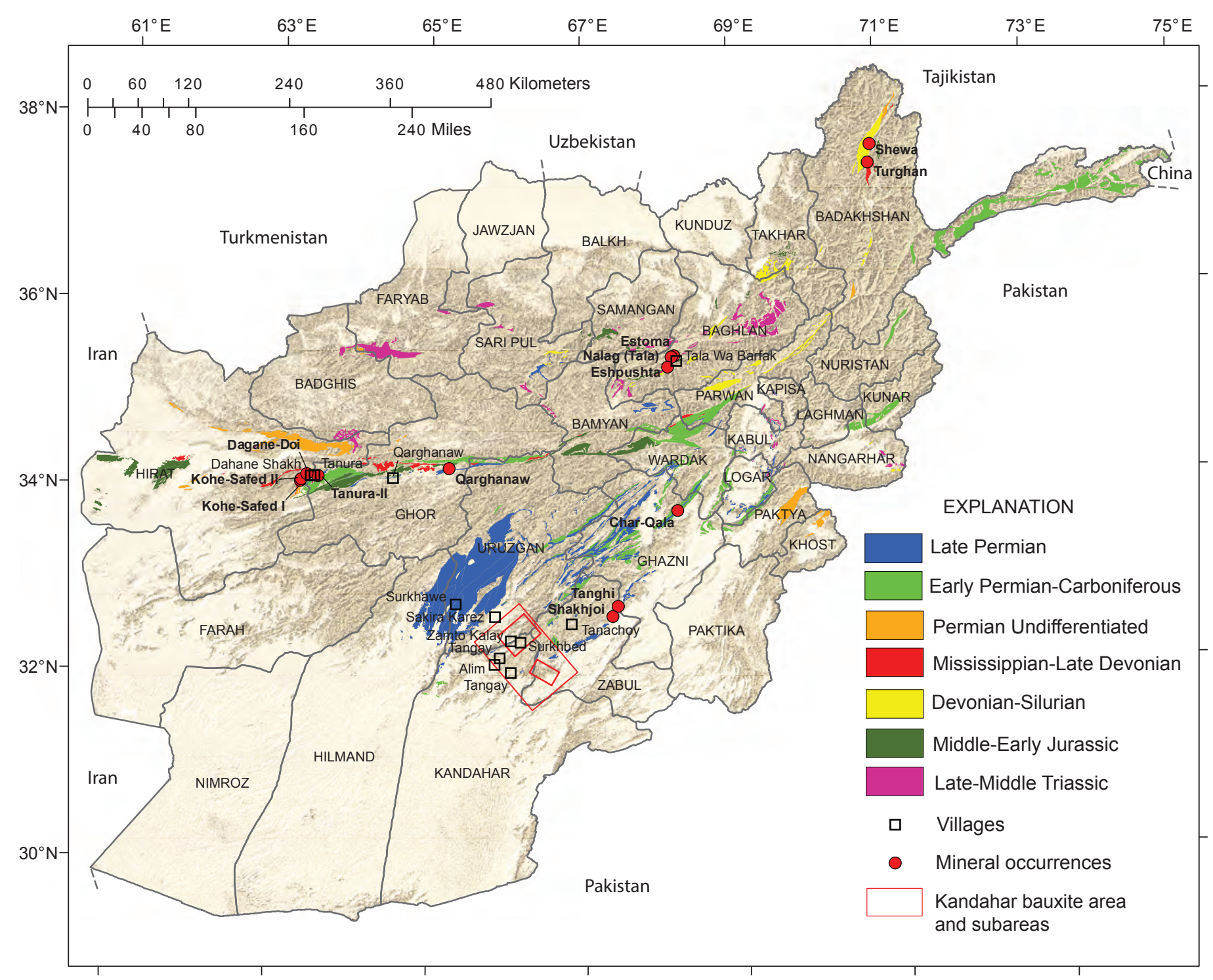

Figure 3. Map of bauxite deposits and occurrences based on map units (Dovgal and others, 1971). 


\section{Description of Bauxite Deposits}

Known bauxite deposits of Afghanistan are of two basic types - those found in karst and those in laterite. They occur in two general areas: laterite-type deposits are located northwest of Kabul, and karst-type deposits have been identified southwest of Kabul.

\section{Laterite-Type Bauxite}

Laterite-type bauxites are composed of weathered residual material in subsoil that formed on weathered aluminous silicate rocks of sedimentary, metamorphic, or plutonic origin, including clay-rich sandstone, gneiss, granite, dolerite, and gabbro. The aluminous rocks are altered by intensive weathering to form bauxite. Bauxites are typically massive, pisolitic, nodular, and earthy. The deposits develop by surficial weathering of well-drained plateaus with warm to hot and wet climates. Locally, deposits may be present in poorly drained areas where iron is removed by organic complexing. The deposits are present on tectonically stable areas. Deposits may be overlain by a thin soil and usually are underlain by saprolite (parent rock in intermediate stages of weathering) (Bárdossy and others, 1990) as shown on figure 4.

Laterite-type bauxite consists mostly of gibbsite or a mixture of gibbsite and boehmite, as well as gangue minerals including hematite, goethite, anatase, and quartz. Residual kaolin deposits are associated with bauxite deposits (Patterson and others, 1967a).

\section{The Laterite-Type Bauxite Complete Profile}

A "standard" profile does not exist because there are no identical laterite or bauxite profiles. Figure 4 illustrates two different profiles, which are based on studies by many scientists. Usually the weathering profile description starts at the top and proceeds downward. The profile shown in figure $4 A$ is composed of five horizons, and the profile shown in figure $4 B$ is composed of six horizons. The first (fig. 4A) is divided into the following (Bárdossy and Aleva, 1990):

1. Soil.-Forms the uppermost horizon; product of mechanical and chemical weathering, mixed with plant remains and humic matter; color depends on various factors.

2. Duricrust horizon.-Upper part, hard to very hard horizon, indurated, commonly concretionary, dark brown to almost black, can be enriched in iron or aluminum oxyhydroxide and kaolinite; in places it directly overlies the saprolite.

3. Bauxite horizon.-Lower section of lateritic part, can be homogeneous or inhomogeneous based on structure (massive beds or layers composed of concretions of various size in soft matrix), texture (aphanitic, pisolitic, gravelly, and breccia-like) and color (pinkish, yellowish, orange to tan, orange to reddish, gray, black); kaolinite is dissolved and replaced by gibbsite to form bauxite. This horizon is usually rich in aluminum and iron.

4. Saprolite horizon.-Composed of aluminum sheet silicate (clay) weathering of parent rock, with the texture and most of the volume of the primary rocks preserved; minerals include kaolinite, quartz, rutile, zircon; usually lighter in colors than the overlaying laterite or bauxite; 2 to 100 meters (m) thick.

5. Parent rock.-Weathering profile is derived from this rock, which influences the nature of the weathering profile.

The profile shown in figure $4 B$ is a more detailed profile, divided into several horizons and zones: (1) modern soil horizon, (2) lateritic paleosol and bauxite horizon, (3) saprolite which includes: (a) lateritic cuirasse (duracrust), (b) bauxite, (c) pallid zone and (d) molted zone, (4) lateritic pedolith, and (5) parent rock (Bárdossy and Aleva, 1990).

\section{Karst-Type Bauxite}

Karst-type bauxite consists of weathered and transported materials that are present in or on carbonate-bearing rocks (fig. 5). The transported material commonly is composed of felsic volcanic ash from distant sources or any aluminous sediment (clay) that was washed into the basin of deposition. These types of bauxites tend to be concentrated in depressions on karst surfaces, and their texture is massive, pisolitic, and earthy. Age of the deposits can be from Paleozoic to Cenozoic. Associated common 


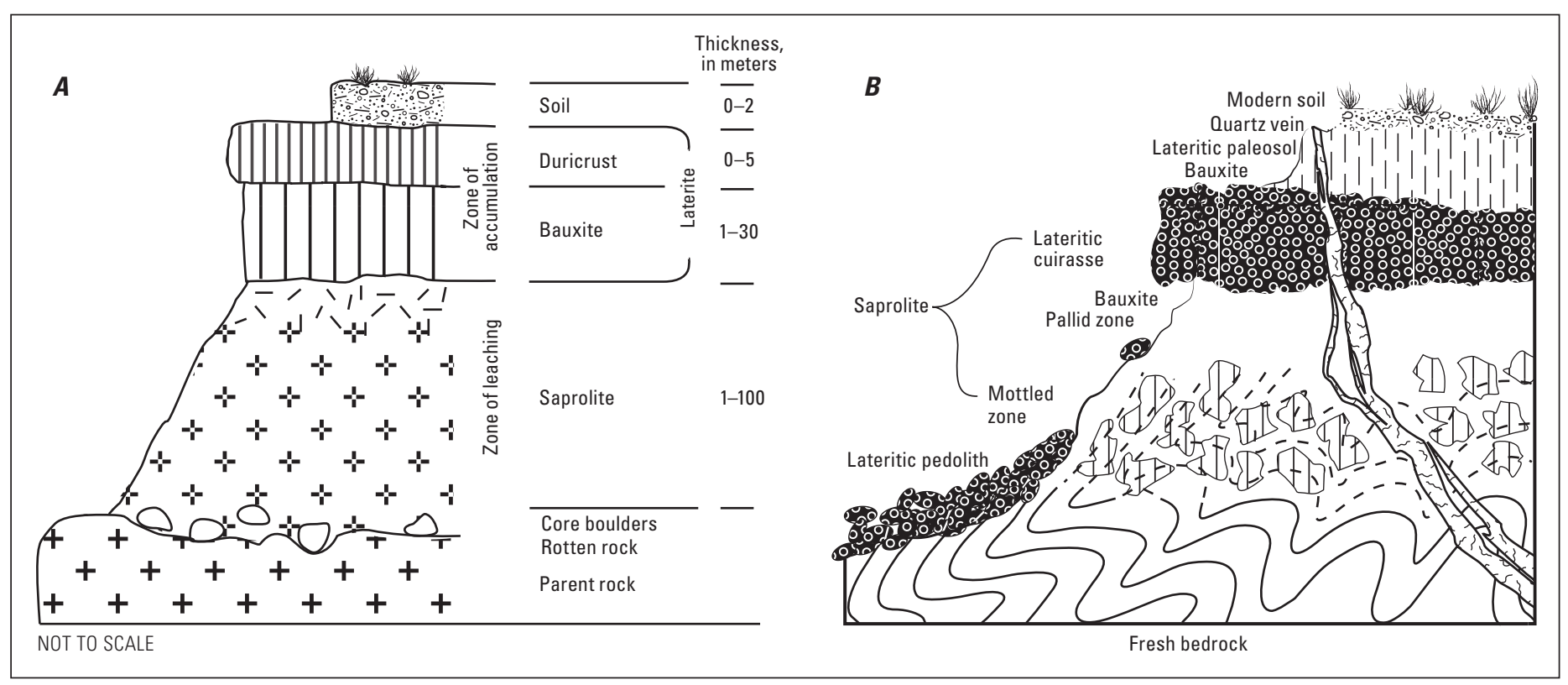

Figure 4. Lateritic bauxite profiles. A, Modified from Bárdossy and Aleva (1990). B, Modified from Retallack (2010).

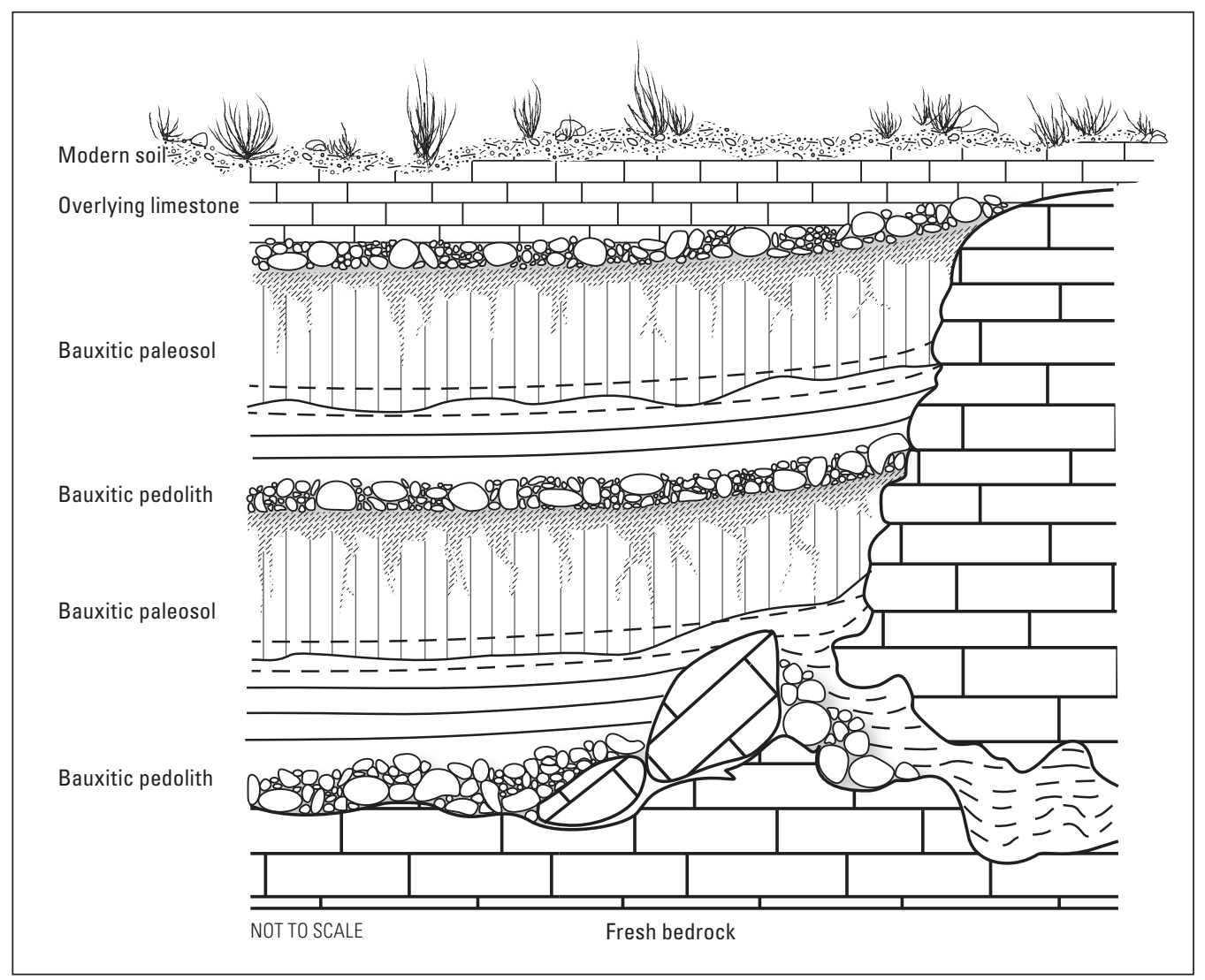

Figure 5. Karst-type bauxite profile (modified from Retallack, 2010). 
rock types are limestone, dolomite, and shale. Some areas are associated with minor coal and are low in iron because of organic complexing and removal of iron during formation (Patterson, 1967b). Karst-type bauxites form from the alteration of aluminous sediments and from continuous intensive weathering, mainly in wet tropical areas. The land masses in those areas were stable, which allowed time for weathering and for protection from erosion.

Karst-type bauxite deposits typically contain mainly gibbsite. Boehmite and gibbsite mixtures also are present in some deposits. Boehmite is more common in Mesozoic and Paleozoic deposits. Gangue minerals in karst-type bauxite deposits are hematite, goethite, anatase, kaolinite, and minor quartz. Geochemically, these deposits are recognized by anomalous aluminum and gallium values (Patterson and others, 1973). A karst-type bauxite deposit in Afghanistan is exemplified by the Obatu Sheila deposit (figs. 2, 3, and 14).

\section{Weathering Products}

Weathering products such as kaolinite are good indicators for residual soils and easy to map by using remote sensing ASTER images. Kaolinite can also be a good indicator for gibbsite formation during the intensive weathering. Gibbsite is an important end product constituent of bauxite deposits because it is easy and cheap to process.

Iron oxide minerals commonly are the end products of weathering of mafic and felsic rocks. Aluminum oxide and hydroxide minerals are an end product of weathering of felsic rocks. Of the aluminum ore minerals, gibbsite has the lowest specific gravity, is the softest, and is more soluble in the Bayer alumina extraction process than boehmite and diaspore. Therefore, gibbsite bauxite is cheaper to process than boehmite and diaspore bauxite (Patterson, 1984).

\section{Kaolinite}

Kaolinite is a clay produced in tropical to subtropical conditions by the intense chemical weathering of aluminum silicate minerals, the most common being feldspars. Kaolinite also has a unique spectral signature, so is easily recognizable in satellite imagery. Mapping the distribution of kaolinite-rich sediments is a critical step in understanding the distribution of these residual soils in Afghanistan.

High-quality kaolin clays are present where the main Lower Jurassic clay bed is $5 \mathrm{~m}$ thick and several hundred meters long (Mikhailov and others, 1965). Near Tala Wa Barfak village, there is a large deposit of foundry clays (mixed clays) and refractory clays (kaolinite) represented by two beds, 2.6 and $4 \mathrm{~m}$ thick and $220 \mathrm{~m}$ in strike length, in the Lower through Middle Jurassic sequence. The clays are of medium plasticity and high caking and dispersion ability. The clay reserves are 385 thousand tons (Mikhailov and others, 1965). 


\section{Description of Bauxite Areas by Region}

\section{Afghanistan-South Pamir Folded Region (Herat (Hirat)-Ghor)}

The Afghanistan-South Pamir folded region includes Haftqala (also spelled Haftkala), Rode Kafgan, and Qarghanaw in the western part of Afghanistan.

\section{Haftqala, Rode Kafghan, Khwaja Morad and Qarghanaw Zones}

The Haftqala zone is in western Afghanistan, in Herat (Hirat) and Ghor Provinces (fig. 2). The Haftqala zone contains the Dagane-Doi bauxite occurrences and the Rode Kafghan zone contains Kohe-Safed and Tanura II bauxite occurrences that are small, separate bauxite bodies and bauxite-bearing rocks, which were identified during construction of roads. They are far away from each other (Dronov and others, 1970, 1973, 1976).

The Haftqala zone is a complex folded structure consisting of rows of anticlines and synclines, which expose a 1,500-m-thick Devonian-Triassic carbonate-bearing section of rocks. The western side of the Haftqala zone is bounded by a thrust fault. The eastern border of the Haftqala uplift is more clearly defined along a fault that defines the transitional boundary to the adjacent Khwaja Morad zone (fig. 6) (Dronov and others, 1970, 1973, 1976).

The Haftqala zone contains Middle Carboniferous through Permian deposits disconformably above Lower Carboniferous strata. The Permian deposits are represented predominantly by quartz sandstone in the lower parts and contain carbonate rocks that include limestone, dolomite, and limy sandstone in the upper parts and are capped by bauxite. The total thickness of the section shown below is 250 to $280 \mathrm{~m}$ (Dronov and others, 1970, 1973, 1976). This section is overlain by Lower Triassic red limestone.

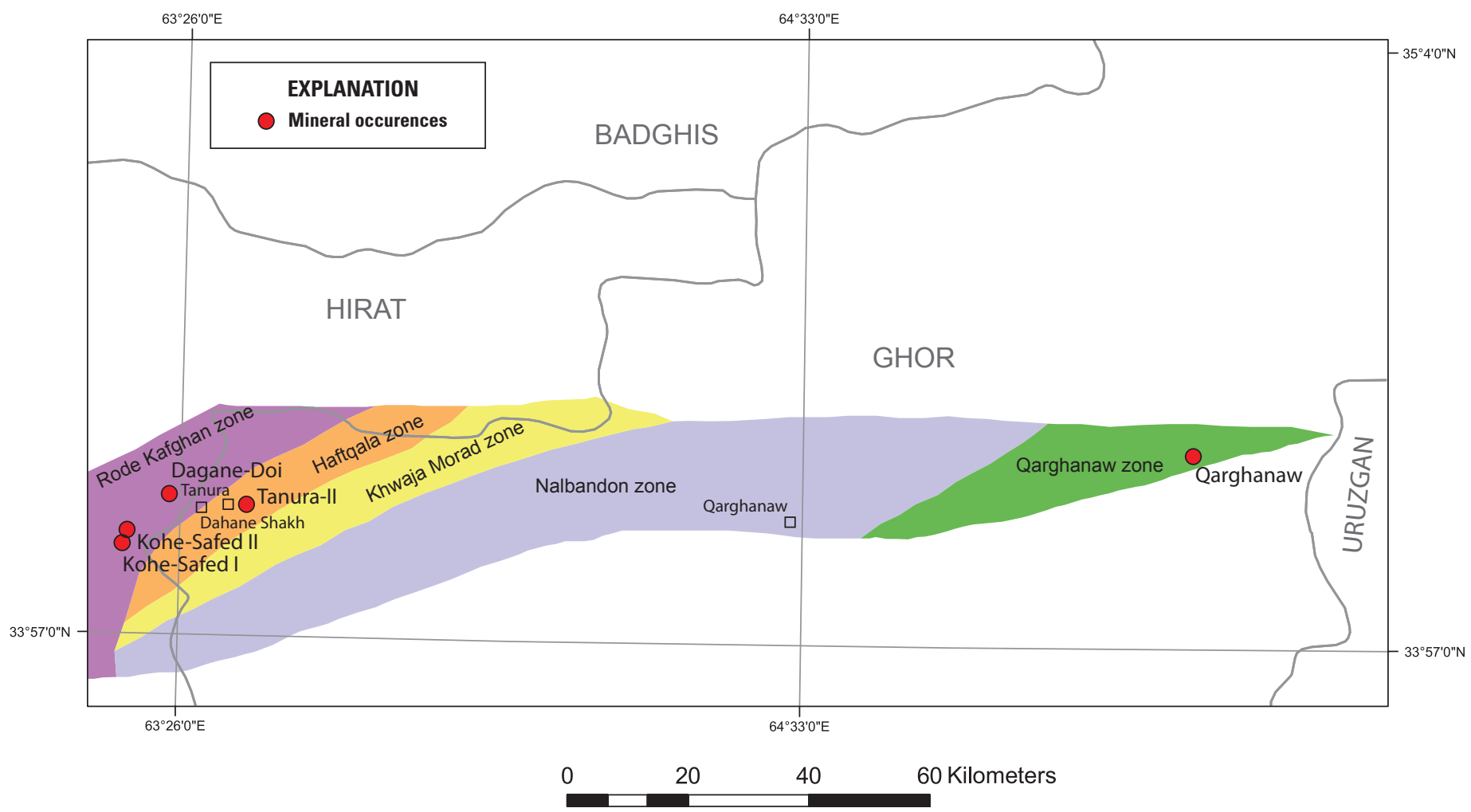

Figure 6. Location of bauxite occurrences in Haftqala, Rode Kafghan, Khwaja Morad and Qarghanaw zones, Herat (Hirat) and Ghor Provinces (bauxites from Dronov and others, 1970; tectonic zones from Peters and others, 2007). 


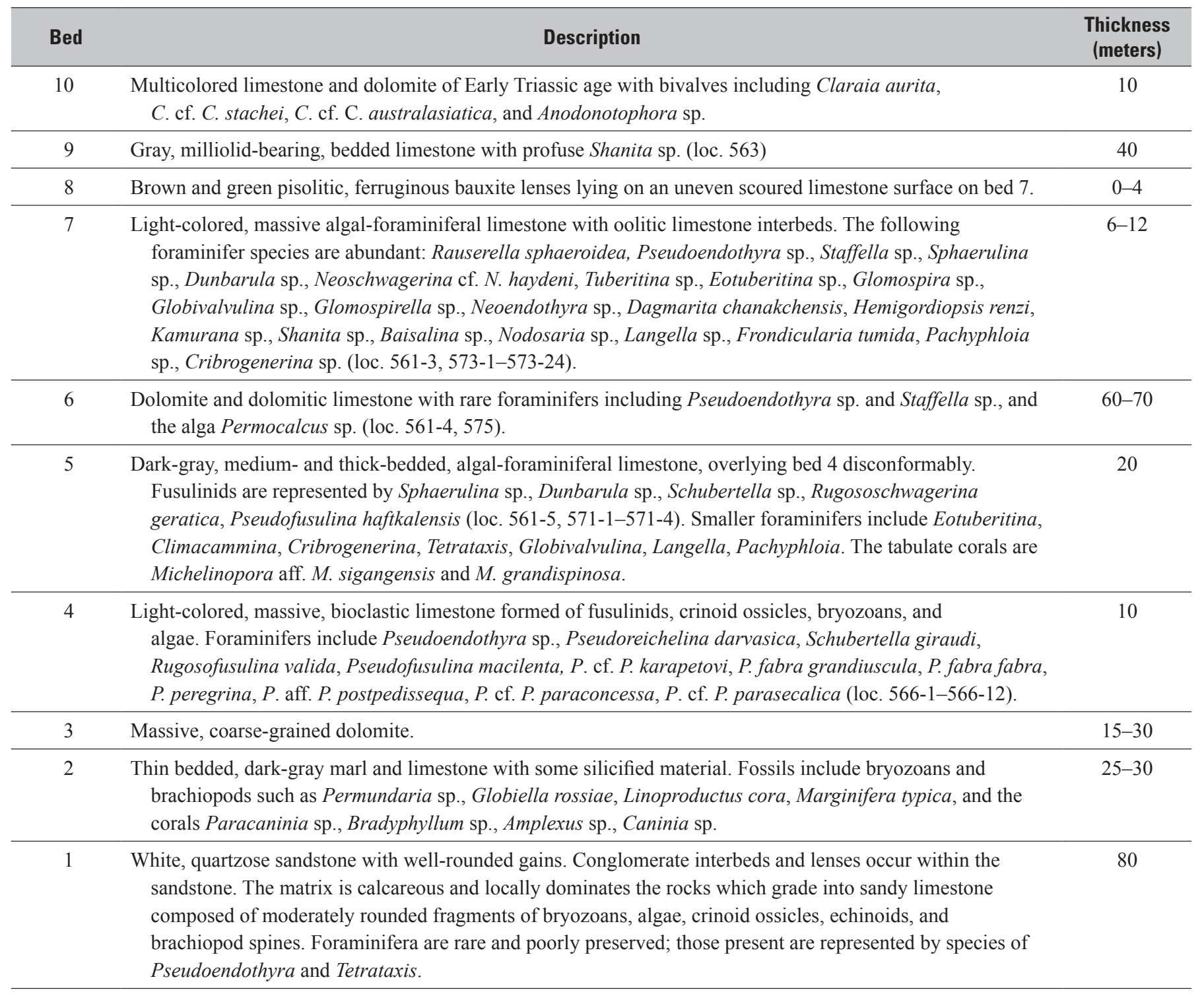

A columnar section for parts of the Haftqala zone is presented in figure 7. 


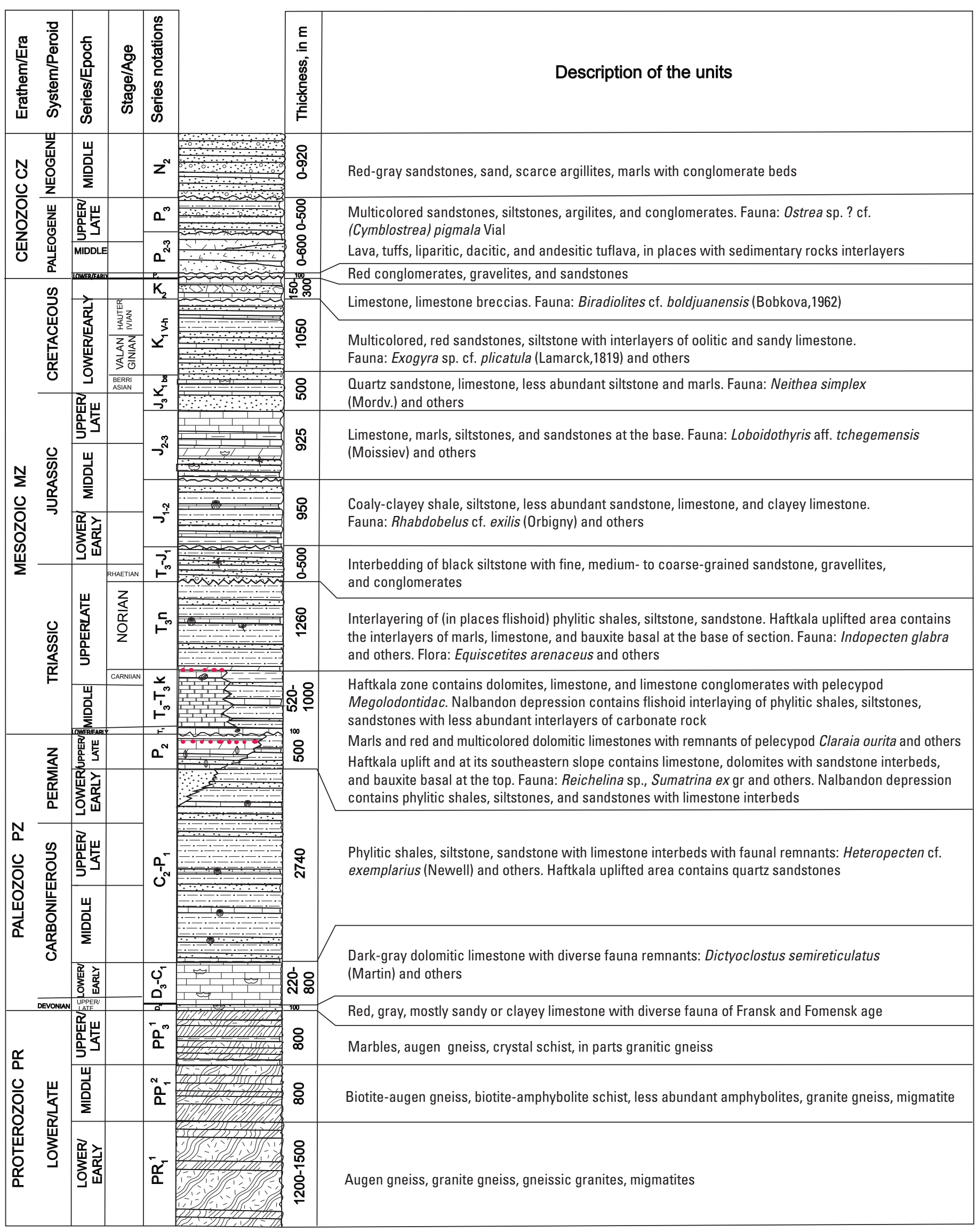

Figure 7. Stratigraphic column, Haftqala zone in Herat (Hirat) and Ghor Provinces (Tutubalin and others, 1979). 


\section{Kohe-Safed I and II Bauxite Occurrences}

The Kohe-Safed I and II bauxite occurrence ( $34^{\circ} 05^{\prime}$ N., $63^{\circ} 20^{\prime}$ E., $34^{\circ} 06^{\prime}$ N., $63^{\circ} 20^{\prime}$ E.) is in Ghor Province (figs. 2 and 3) and is confined to the Pamir (upper Permian) stratigraphic horizon (fig. 7). It contains two lens-shaped bauxites that are 1.5 and $2.5 \mathrm{~m}$ thick, respectively, and the exposed surfaces are from 15 to $20 \mathrm{~m}$ long (Dronov and others, 1970). The bauxite outcrops are 70 to $100 \mathrm{~m}$ apart from each other on top of early Permian white bioclastic limestone at the base of the upper Permian limestone. The bauxites are rusty red, brown, dull greenish, or greenish yellow and pisolitic. Each lens was channel sampled every $0.5 \mathrm{~m}$ along the strike, with three samples collected from each lens for a total of six samples (lens 1, samples 576/1-3; lens 2, samples 577/1-3). The contents are as follows: 40.16 to $48.66 \mathrm{wt} \% \mathrm{Al}_{2} \mathrm{O}_{3}, 6.88$ to $23.32 \mathrm{wt} \% \mathrm{SiO}_{2}$, and 17.19 to $25.03 \mathrm{wt} \% \mathrm{Fe}_{2} \mathrm{O}_{3}$ (Doronov and others, 1970). The results of chemical analysis are in table 3.

The Kohe-Safed bauxite occurrence was recommended by Dronov and others (1970) as a prospective area for identifying more bauxite. Although $\mathrm{Al}_{2} \mathrm{O}_{3}: \mathrm{SiO}_{2}$ ratios of the samples in table 3 are fairly high, the Kohe-Safed deposit falls slightly short of being compatible with industrial-grade bauxite (table 1).

Table 3. Results of chemical analysis of the Kohe-Safed bauxite occurrence (from Dronov and others, 1970).

[ID, identifier; - , no data; NI, not identified]

\begin{tabular}{|c|c|c|c|c|c|c|c|c|c|c|c|}
\hline \multirow{2}{*}{$\begin{array}{c}\text { Sample } \\
\text { ID }\end{array}$} & \multicolumn{11}{|c|}{ Content, in weight percent } \\
\hline & $\mathrm{SiO}_{2}$ & $\mathrm{Al}_{2} \mathrm{O}_{3}$ & $\mathrm{Fe}_{2} \mathrm{O}_{3}$ & $\mathrm{TiO}_{2}$ & $\mathrm{MnO}$ & $\mathrm{P}_{2} \mathrm{O}_{5}$ & $\mathrm{CaO}$ & $\mathrm{MgO}$ & Other & $\mathrm{H}_{2} \mathrm{O}$ & $\Sigma$ \\
\hline $576 / 1$ & 8.49 & 46.87 & 22.60 & 6.63 & 0.07 & 0.02 & 7.11 & - & 12.92 & 0.555 & 99.71 \\
\hline $576 / 2$ & 12.70 & 40.16 & 25.03 & 5.70 & 0.04 & - & 2.87 & 0.43 & 12.41 & 0.90 & 99.54 \\
\hline $576 / 3$ & 15.64 & 43.95 & 19.77 & 5.85 & 0.07 & 0.03 & 2.11 & 1.4 & 12.18 & 1.09 & 100.32 \\
\hline $577 / 1$ & 23.32 & 40.44 & 17.19 & 5.63 & NI & NI & NI & NI & NI & NI & NI \\
\hline $577 / 2$ & 6.88 & 48.66 & 24.00 & 6.55 & 0.04 & 0.03 & 1.71 & - & 12.60 & 0.67 & 99.97 \\
\hline $577 / 3$ & 11.53 & 45.45 & 23.41 & 5.74 & 0.07 & 0.03 & 2.11 & - & 11.52 & 0.80 & 99.86 \\
\hline
\end{tabular}

\section{Tanura-II Bauxite Occurrence}

Tanura-II bauxite occurrence is northwest of Tanura village (3409'41" N., 63²4'50" E.; figs. 2 and 3; Dronov and others, 1970). Aluminum-bearing rocks are in small irregular bodies $(0.5$ by $1 \mathrm{~m})$ in upper Norian (Triassic) sandy-silty beds, which are on the erosion surface on top of middle through lower Norian bioclastic limestone. Macroscopically, the rocks are similar to the Kohe-Safed rocks. The bauxite-bearing rocks are greenish yellow and rusty and pisolitic. The results from geochemical analysis are listed in table 4.

\section{Dagane-Doi Bauxite Deposit}

The Dagane-Doi deposit lie in a transitional zone between the Haftqala zone and the Khwaja Morad zone (3409'37" N., 63³2'54" E.; figs. 2 and 3). This transitional zone was named the Sange Doshah zone by Abdullah and others (2008) but was included in the Haftqala zone by Peters and others (2007). The mineralization consists of two outcrops of rusty-red and green-yellow, pisolitic, dense, sandy rocks. The two lensshaped bauxites ( 3 by $5 \mathrm{~m}$ and 4 by $10 \mathrm{~m}$ ) are developed on an erosion surface on top of lower Permian bioclastic limestone, conformably overlain by upper Permian sandstone. Geochemical results of samples collected in a 3- by 5-m area and in a 4- by $10-\mathrm{m}$ area in the small gully at the depth $3.4 \mathrm{~m}$ (lens I, sample 633/3; lens II, sample 633/6) are listed in table 5 (Dronov and others, 1970).
Table 4. Geochemical results for the Tanura-II bauxite occurrences (from Dronov and others, 1970).

[ID, identifier]

\begin{tabular}{crrrr}
\hline \multirow{2}{*}{$\begin{array}{c}\text { Sample } \\
\text { ID }\end{array}$} & \multicolumn{4}{c}{ Content, in weight percent } \\
\cline { 2 - 5 } & $\mathbf{S i O}_{2}$ & $\mathbf{A l}_{2} \mathbf{O}_{3}$ & $\mathrm{Fe}_{2} \mathbf{O}_{3}$ & $\mathrm{TiO}_{2}$ \\
\hline $576 / \mathrm{B}$ & 7.91 & 10.74 & 1.57 & 1.37 \\
$576 / \mathrm{v}$ & 11.81 & 11.36 & 2.86 & 1.55 \\
\hline $576 / 2$ & 15.64 & 43.95 & 19.27 & 5.85 \\
\hline $577 / 1$ & 37.59 & 36.31 & 7.29 & 3.05 \\
\hline
\end{tabular}

Table 5. Geochemical results of samples from the Dagane-Doi bauxite occurrences (from Dronov and others, 1970).

[ID, identifier]

\begin{tabular}{cccrc}
\hline \multirow{2}{*}{$\begin{array}{c}\text { Sample } \\
\text { ID }\end{array}$} & \multicolumn{4}{c}{ Content, in weight percent } \\
\cline { 2 - 5 } & $\mathbf{S i}_{2}$ & $\mathbf{A l}_{2} \mathbf{0}_{3}$ & $\mathbf{F e}_{2} \mathbf{O}_{3}$ & $\mathbf{T i}_{2}$ \\
\hline $633 / 3$ & 41.18 & 29.64 & 9.15 & 3.35 \\
$633 / 6$ & 36.99 & 28.65 & 18.02 & 5.62 \\
\hline
\end{tabular}


The $\mathrm{Al}_{2} \mathrm{O}_{3}$ content and $\mathrm{Al}_{2} \mathrm{O}_{3}: \mathrm{SiO}_{2}$ ratio (table 5) indicate that the rocks from the Dagane-Doi and Tanura-II bauxite occurrences may not be industrial-grade deposits (table 1). Kohe-Safed mineralization is closer to the industrial mark but still slightly below. It was proposed by Soviet geologists that the Haftqala zone may contain many more bauxite bodies similar to the described bauxite bodies that remain undiscovered (Dronov and others, 1970). This inference is based on paleogeographic conditions during the Permian and Triassic periods (tropical climates, common exposure surfaces, dominant carbonate deposition). This area is recommended for further investigation.

The section was described in detail by Russian geologists is near Dane Shah village. The lower parts of the section begin with a carbonate bed unconformably overlain by largely terrigenous deposits of Middle Carboniferous through lower Permian age. The stratigraphy in this area is as follows:

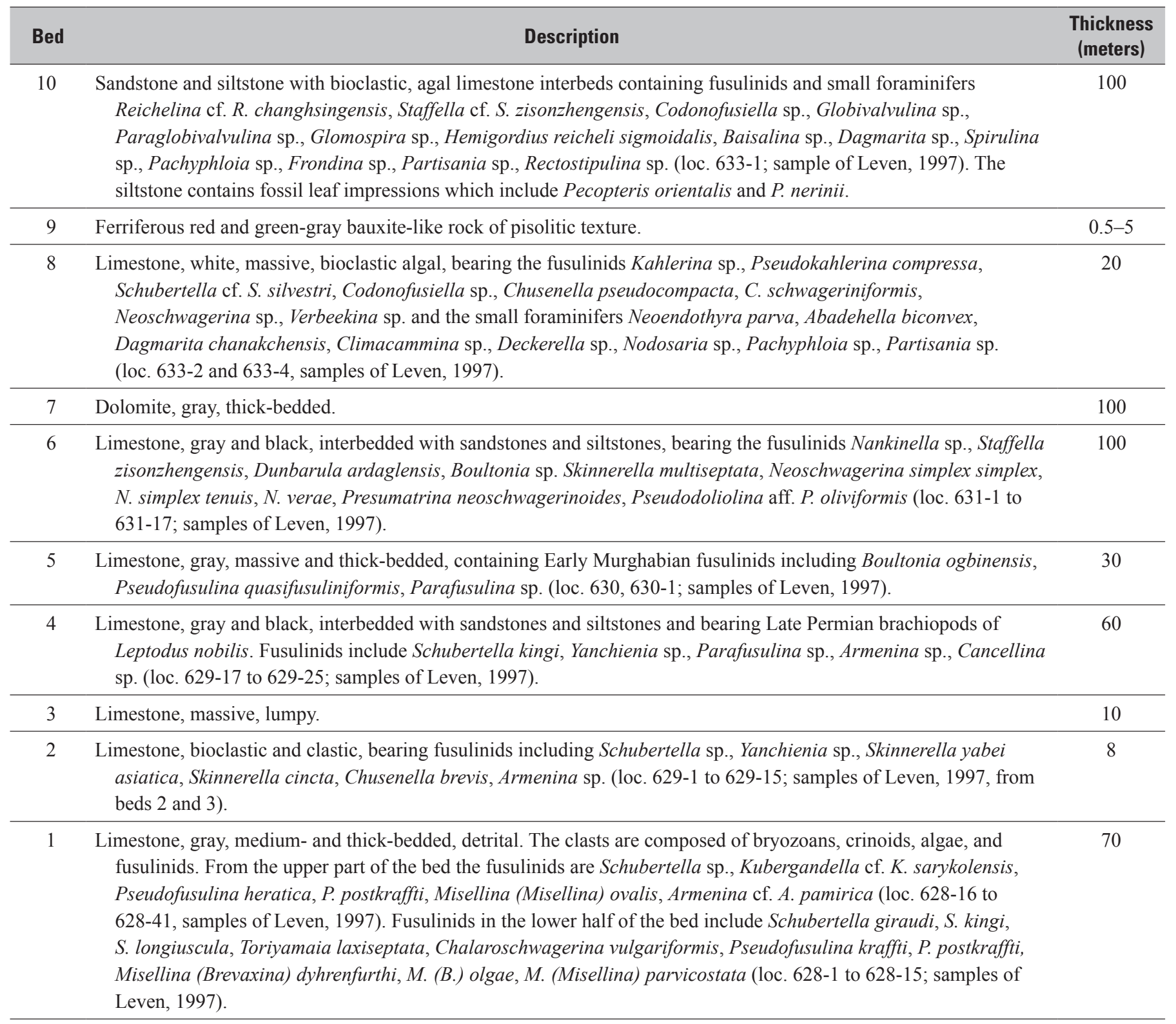




\section{Qarghanaw Bauxite Occurrence}

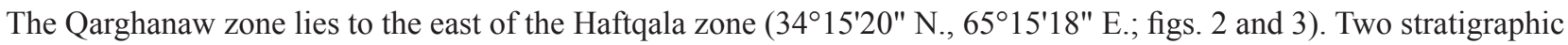
sections were measured, one Permian (Leven, 1997) and the other Triassic (Dronov and others, 1973). The Permian sequence in the Qarghanaw zone, located southeast of the Nalbandan zone, is generally similar to others in western middle Afghanistan. A minor difference is that the upper part of the siliciclastic Carboniferous through lower Permian group is altered volcanic rocks up to $400 \mathrm{~m}$ thick. North of the village of Qarghanaw, the volcanic rocks are overlain, apparently conformably, by the following sequence (Leven, 1997; Dronov and others, 1973):

\begin{tabular}{|c|c|c|}
\hline Bed & Description & $\begin{array}{c}\text { Thickness } \\
\text { (meters) }\end{array}$ \\
\hline 6 & Dolomite, thick-bedded. & 40 \\
\hline 4 & Dirty, green-gray, pisolitic siliceous rocks lying on a rough limestone surface [a soil]. & 10 \\
\hline 3 & $\begin{array}{l}\text { Black, bioclastic, detrital limestone with rare chert nodules and sandstone and siltstone interbeds. Limestone contains } \\
\text { foraminifers including Staffella sp., Nankinella sp., Pseudofusulina aff. P. solita, Parafusulina sp., Neoschwagerina } \\
\text { sp., Yabeina sp., Armenina sp., Pseudodoliolina sp., and Sumatrina sp. (loc. 1405-8). }\end{array}$ & 40 \\
\hline 2 & Thick-bedded, gray limestone. & 40 \\
\hline 1 & $\begin{array}{l}\text { White, massive reefal limestone with the foraminifers Stafella zisongzhengensis, Nankinella inflata, Schwagerinidae } \\
\text { gen. indet., Hemigordiopsis sp., and the algae Mizzia velebitana, Permocalcus tenellus (loc. 837, 837-1). A fault } \\
\text { separates beds } 1 \text { and } 2 \text {. }\end{array}$ & 100 \\
\hline
\end{tabular}

In the Qarghanaw zone, the Induan-Carnian (Triassic) sequence exhibits a different succession of beds as compared to Nalbandan and Khwaja Morad. The section described from the Mene Bum Ravine is as follows. Permian dolomites are overlain disconformably by the following beds (Leven, 1997; Dronov and others, 1973):

\begin{tabular}{clcc} 
Bed & & Description & $\begin{array}{c}\text { Thickness } \\
\text { (meters) }\end{array}$ \\
\hline 6 & Dolomite, thick-bedded. & 20 & 30 \\
\hline 5 & $\begin{array}{c}\text { Bauxite of pisolitic and fine-grained texture, variegated, with a well-defined horizon of gray limestone abounding in } \\
\text { gastropod and pelecypod remains of Carnian appearance in the middle part. }\end{array}$ & 30 \\
\hline 4 & Dolomite, gray and dark, layered, occasionally fragmental. & 20 \\
\hline 3 & Limestone, black, layered, argillaceous with rare chart nodules, lenses and bands. & 40 \\
\hline 2 & Limestone, gray, occasionally lumpy, with crinoid and pelecypod remains in the upper portion. & 200 \\
\hline 1 & Limestones, dark and gray, thin-bedded with abundant remains of mud-eaters and algae at the bedding surfaces.
\end{tabular}

The thickness of the sequence is $340 \mathrm{~m}$. By the position in the section and by comparison with similar deposits from other zones, bed $1(200 \mathrm{~m})$ corresponds to Lower Triassic to Anisian deposition and beds 2 to 6 (140 m) to Ladinian to Carnian deposition. The distinctive feature of the Lower Triassic through Carnian beds from the Qarghanaw zone as compared with those of the Nalbandan zone is the greater thickness of the beds (and particularly that of the Lower Triassic through Anisian flaggy limestones), the absence of limestone conglomerates at the base, a gap in the Carnian sequence, and the presence of bauxite and dolomite (Leven, 1997; Dronov and others, 1973). 


\section{Afghanistan-North Pamir Folded Region (Badakshan)}

\section{Faydz Abad and Safed Hers Bauxite Zones}

The Faydz Abad and Safed Hers bauxite zones are in central Badakshan Province, and are characterized by a complex structural setting. The bauxite zone contains many faults of different scales and genesis; specifically, overthrusted sheets in different allochthonous complexes. In places the lithological relations among sections is unclear. Many formations in the zone, especially the Paleozoic stratigraphic sections, appear to be allocthonous; the facies are juxtaposed by strong horizontal movement in Alpine-style thrusting. The Faydz Abad and Safed Hers bauxite zones are in the form of a wedge that pinches out southward. Neoproterozoic and Vendian formations form the basement in the northeast side of the Faydz Abad zone (Sborshchikov and others, 1973).

\section{Shewa Bauxite Occurrence}

The Shewa bauxite occurrence (Sborshchikov and others, 1973; 37³8'25" N., 70 53'05" E.; figs. 2 and 3) is in the Faydz Abad zone. The bauxite layer is $1.0 \mathrm{~m}$ thick and lies in the middle parts of the Permian section. The bauxite is tan-green, mottled, dense, and pisolitic. The bauxite beds lie on a faintly expressed erosion surface on top of dolomite and are overlain by a thick gray limestone. The fossiliferous Permian rocks are present in a narrow thrust sheet, which extends for 13 kilometers $(\mathrm{km})$ from north to south along the confluence of the Shewa and Turghan Rivers. The Permian deposits in this area are typified by a stratigraphic section on the west slope of the Shewa River Valley near the confluence with the Turghan River (Sborshchikov and others, 1973). The Permian beds in this area are overturned. They lie in fault contact with Lower Ordovician limestone in the east and Upper Triassic sandstones and siltstones in the west. The Permian stratigraphic section in this area has the following succession from east to west (the rocks were described by Dronov and others, 1975, and Sborshchikov and others, 1973):

\begin{tabular}{clc} 
Bed & \multicolumn{1}{c}{ Description } & $\begin{array}{c}\text { Thickness } \\
\text { (meters) }\end{array}$ \\
\hline 6 & $\begin{array}{c}\text { Gray limestone, medium-bedded, detrital; has red-colored coating on the surface and contains crinoids, bryozoans, and } \\
\text { Schwagerinidae fusulinids. }\end{array}$ & 70 \\
& Rusty-green bauxite, mottled, with pisoidal texture dense with an erosional surface at the base. & 2 \\
\hline 5 & Dull-gray, pale-reddish at top, thick-bedded dolomite. & 10 \\
\hline 4 & Black, calcareous siltstone with interbedded quartzose sandstone that contains the Lower Permian brachiopod \\
& Reticularia sp. & 60 \\
\hline 2 & Volcanic tuff? & 10 \\
\hline 1 & Dull-gray, thick-bedded dolomite with a 2-m pale rusty limestone at the top. & 100 \\
\hline
\end{tabular}


The total thickness of this section is $252 \mathrm{~m}$. The age of the beds of the described section is lower Permian, based on the brachiopod fauna below and the fusulinid fauna above the bauxite bed. The lower Permian rocks in this area formed in a nearshore environment indicated by the mixture of thin layers of rock, an erosion surface, a bauxitic soil, marine fossils, and quartz sandstone (Sborshchikov and others, 1973; fig. 8).

\begin{tabular}{|c|c|c|}
\hline 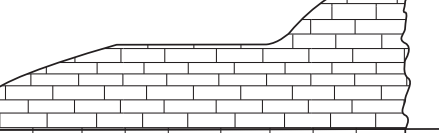 & 70 & $\begin{array}{l}\text { Gray limestone; the surface and layers have red coating; medium-bedded, fragmental- } \\
\text { detrital with remnants of crinoids, broyozans, and microfauna }\end{array}$ \\
\hline 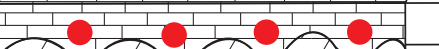 & 2 & Bauxites are rusty-green, mottled with pisoidal texture, traces of erosion at the bottom \\
\hline$,,,,, 1,1,,, 1$, & 10 & Dull-gray, pale-reddish at the surface, thickbedded \\
\hline$a_{\infty}$ & 60 & $\begin{array}{l}\text { Black, limy siltstone with beds of multigrained quartz sandstones } \\
\text { and remnants of brachiopods }\end{array}$ \\
\hline+++++++++1 & 10 & Volcanogenic? Acidic rocks? \\
\hline 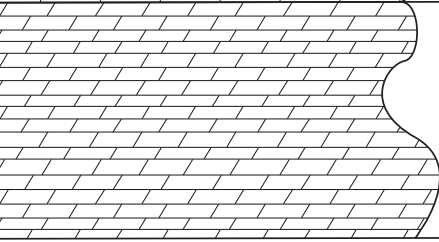 & 100 & $\begin{array}{l}\text { Dull-gray dolomites, pale-reddish on the surface, thickbedded; contain 2-m-thick layer } \\
\text { of gray limestone }\end{array}$ \\
\hline
\end{tabular}

NOT TO SCALE

Figure 8. Section of Permian deposits in Shewa River Valley (Sborshchikov and others, 1973).

\section{Turghan Bauxite Occurrence}

The Turghan bauxite occurrence (Sborshchikov and others, 1973; 37²6'16" N., 7050'55" E.) lies in the same zone as the Shewa bauxite occurrence, $10 \mathrm{~km}$ from the Shewa occurrence. The bauxite-bearing bed is $2.0 \mathrm{~m}$ thick and occurs in a multicolored Permian section (Sborshchikov and others, 1973).

\section{South Afghanistan Region (Kandahar, Zabul, Ghazni, and Uruzgan)}

Bauxites in the South Afghanistan structural region lie within the Tirin and Arghandab blocks of the Central Afghan Massif in Kandahar, Zabul, Ghazni, and Uruzgan Provinces (fig. 2). The Central Afghan Massif is elongated, contains large faults, and is covered by Neogene deposits in the Seistan Valley. The massif consists of two sections. The eastern section (Helmand (Hilmand)-Arghandab block) is uplifted. The western section consists of folded volcanic, carbonate, terrigenous deposits (Dovgal and others, 1971; Karapetov and others, 1970; Dronov and others, 1972).

The Arghandab block extends through Kandahar, Zabul, and Ghazni Provinces. It contains bauxite deposits and occurrences. The Arghandab block in Ghazni Province contains the Char-Qala bauxite occurrence; in Zabul Province the occurrences are the Sakhjoi and Tanghi. The Arghandab block in Kandahar Province contains the largest deposits: Obatu Sheila, Archa Ghar, and Zamto Kalay. Deposits related to the Obatu Sheila occur in the Tirin block.

The Arghandab block was first defined by Dovgal and others (1971) and Karapetov and others (1970). The outlines of the block were revised by Dronov and others (1972), who included in the block the peripheral part of the Helmand (Hilmand)Arghandab Uplift, which is southeast of the granitoid massifs of the Arghandab Complex. The northwest boundary of the block is bounded by granitoids, and the southeast boundary is the Mukur-Tarnak fault. The Arghandab block is lensoidal in shape, extending for $250 \mathrm{~km}$ in length and up to $40 \mathrm{~km}$ in width. It has a northeast strike (Dovgal and others, 1971; Karapetov and others, 1970; Dronov and others, 1972). 
The Arghandab block consists of lower and upper sections. The lower section consists of two Neoproterozoic folded complexes (Malakhel and Malestan). The folded basement consists of Mesoproterozoic and Neoproterozoic rocks. In the present structural pattern, the basement rocks crop out in a number of antiformal structures, the largest of which is the Malakhel arch. Sedimentary rocks are common in this block as compared to other uplifts. The upper section of the Arghandab block consists of uppermost Proterozoic through Cretaceous sedimentary deposits, 9,000 m thick. The block is highly dislocated and includes isoclinal folds. Vendian through Cambrian carbonate beds $(870 \mathrm{~m})$ are overlain by Ordovician to lower Permian fine-terrigenous beds $(4,335 \mathrm{~m})$, which are in turn overlain by upper Permian through Jurassic carbonate rocks $(3,870 \mathrm{~m})$ that are disrupted by a Rhaetian through Liassic terrigenous interval $(40-600 \mathrm{~m})$. The Cretaceous is represented by Barremian through Aptian coarseand fine-grained terrigenous beds $(450-1,365 \mathrm{~m})$. The total thickness of the sedimentary strata ranges from 6,250 to $10,000 \mathrm{~m}$. Quartz sandstone is abundant in the Silurian, Devonian, and Carboniferous rocks, and dolomite is abundant in the upper Permian and Middle through Upper Triassic parts of the sequence. Indications of erosion are observed at three levels: inside the Frasnian, at the base of the Artinskian, and at the base of the Upper Jurassic. Bauxite is present in this section at the second and third erosional levels. The Barremian-Aptian sequence lies unconformably on all the older formations. As in other areas of the uplift, the sedimentary strata are deformed to folded in short, broad, linear, gently dipping, shallow folds. Monoclinal bedding is observed in many areas, and angles of the limbs of the folds and monoclines range from $15^{\circ}$ to $20^{\circ}$ up to $50^{\circ}$ to $70^{\circ}$. Disharmonic folding is traceable in the more ductile stratigraphic intervals. Devonian, Permian, and Jurassic sections contain major erosional surfaces, with bauxite having developed in the latter two periods (Karapetov and others, 1970; Dovgal and others, 1971; Dronov and others, 1972).

The Tirin block is between the Helmand (Hilmand) and Arghandab blocks. The sedimentary cover consists of Upper Devonian to Jurassic carbonate-terrigenous rocks that total 4,300 $\mathrm{m}$ in thickness, separated by an erosional surface from an upper complex that consists of a Lower Cretaceous, continental, thin terrigenous section which is $600 \mathrm{~m}$ thick. Bauxite is developed on an unconformable surface between Middle and Upper Jurassic sediments (Karapetov and others, 1970; Dovgal and others, 1971; Dronov and others, 1972).

\section{Ghazni (Ganzi) Province, Arghandab Block}

\section{Char-Qala Bauxite Occurrence}

Char-Qala bauxite occurrence is located in Ghazni Province (33 $46^{\prime}$ N., $68^{\circ} 12^{\prime}$ E.; figs. 2 and 3). The bauxite layers are on an erosional surface at the top of Lower Permian terrigenous beds. They are immediately overlain by Artinskian limestone. Five lens-shaped bauxites, ranging in thickness from 8 to $25 \mathrm{~m}$ and exposed over $100 \mathrm{~m}$ of the strike length, with individual outcrop lengths of 10 to $30 \mathrm{~m}$, have been discovered at the bottom of the Artinskian limestone in the section of Carboniferous through lower Permian sequence (Karapetov and others, 1970). The bauxites are brown, greenish-gray, red, and dirty green; pisolitic; and massive, locally exhibiting vague bedding. The samples taken by Russian geologists contain $40.37 \mathrm{wt} \%$ and $49.95 \mathrm{wt} \%$ $\mathrm{Al}_{2} \mathrm{O}_{3}$ and $2.74 \mathrm{wt} \%$ and $5.88 \mathrm{wt} \% \mathrm{SiO}_{2}$, respectively (Dronov and others, 1972). Based on chemical analysis from the channel samples, the content of $\mathrm{Al}_{2} \mathrm{O}_{3}$ ranges from 40 to $50 \mathrm{wt} \%$.

\section{Zabul Province, Arghandab Block}

In this area the Arghandab block contains two bauxite occurrences: Sakhjoi and Tangi. Both occurrences are in the Permian Chohan Formation. The Chohan Formation contains dark-gray (gray at the surface), laminated, and thick-bedded dolomitic limestone, $900 \mathrm{~m}$ thick. The bottom of Chohan Formation limestone (10-15 m) contains foraminifera similar to Darwazian and Murgabian stages (Middle Permian): Ammodiscidae gen. indet., Pachyphloia sp., and Nankinella sp. To the south from Sakhjoi, rugose corals were determined: Yatsengia aff. Y. bukiensis, Y. cf. asiatica, Carinthiaphyllum cf. maclayi, Waagenophyllum aff. wengchengense, and $W$. aff. indicum, which characterize the Darwaz and Murgab Formations. In the upper beds of the Chohan the following fossils were collected: Reichelina cf. media, Geinitzina cf. caucasica, Nodosaria aff. acera, Pachyphloia cf. multiseptata, $P$. aff. robusta, and Colaniella cf. cylyndrica. These fossils indicate a Pamirian (upper Permian) correlation. On the basis of the fossils, the Chohan is middle to late Permian in age (Dronov and others, 1972).

The Chohan Formation has a transgressive unconformable lower contact; it is conformably overlain by Triassic beds. The Chohan formation rocks rest on various horizons including Precambrian and lower and upper Paleozoic beds. The content of Permian basal layers varies according to the horizon they overlie. The unconformity between Permian basal beds and 
Precambrian metamorphic beds to the south of Davlatel is sharp and angular. The basal beds of the Chohan Formation contain $1 \mathrm{~m}$ of granular, brown-yellow conglomerate, followed by green siltstones, $2 \mathrm{~m}$ thick. The siltstones grade into laminated light-gray and yellow limestone beds, $10 \mathrm{~m}$ thick, with interbeds of granular conglomerate, $0.3 \mathrm{~m}$ thick (Dronov and others, 1972).

Permian limestone overlies carbonate rocks of the Cambrian through Lower Ordovician Zargaran Formation with an angular unconformity that shows 15 to $200 \mathrm{~m}$ of relief. The basal bed contains bright-colored bauxite from 2 to $5 \mathrm{~m}$ thick that is pisolitic and contains rock fragments. The content of $\mathrm{Al}_{2} \mathrm{O}_{3}$ in the samples from several pit holes is low, from 23 to $24 \mathrm{wt} \%$. The bauxites grade along the strike into iron-rich pebble conglomerates $(5$ to $7 \mathrm{~m}$ ) with well-rounded quartz and chert grains (Dronov and others, 1972).

Where the Chohan Formation overlies Carboniferous quartz sandstone beds, the angular unconformity is absent. The basal beds are coarse pebble and cobble conglomerates from 4 to $5 \mathrm{~m}$ thick. The quartz sandstone cobbles are from 30 to $40 \mathrm{~cm}$ in diameter and well rounded (Dronov and others, 1972).

The Chohan Formation is present in many areas including upstream of the Arghandab River and along the west bank of the Tirin River. In the middle reaches of the Arghandab River, the Chohan Formation crops out as a narrow elongate broken strip for more than $160 \mathrm{~km}$, from Lar village in the northeast to Mukrak village to the southwest. Isolated outcrops occur near Faten Mohammad village, Malikhel village, Shal Kalay, Dewkhana, Hajian, and Takhamak. The Chohan Formation overlies dolomites of the Cambrian(?), and contains conglomerates, bauxite, and bauxitic rocks 2 to $3.5 \mathrm{~m}$ thick at its base above the Zargaran Formation (Dronov and others, 1972).

\section{Sokhjoi Bauxite Occurrence}

The Sokhjoi bauxite occurrence ( $32^{\circ} 38^{\prime} 27^{\prime \prime}$ N., $67^{\circ} 21^{\prime} 8^{\prime \prime}$ E.) is within the Chohan Formation, which unconformably overlies a weakly karsted dolomitic limestone surface of the Zargaran Formation. There are two outcrops of bauxite to the northeast and southeast of each other (fig. 9). The northeastern outcrop extends as far as 4 to $5 \mathrm{~km}$ and gently dips at $15^{\circ}$ to $20^{\circ}$. The northeastern outcrop is described by Karapetov and others (1970). The southwestern outcrop extends as far as 2 to $3.5 \mathrm{~km}$.

The bauxites range from 0 to $5 \mathrm{~m}$ and average 3 to $4 \mathrm{~m}$ in thickness. The bauxites are brownish, greenish-yellow, and jasperlike and ferruginous in places, with pisolites and rock fragments. The pisolites range from 1.0 to $1.5 \mathrm{~cm}$ up to several centimeters in diameter. The pisolites gradually disappear upwards in the section. The upper part of the section contains greenish, layered, clayey bauxite. The clayey bauxites locally are completely replaced by conglomerates with chert, quartz, and limestone pebbles. The basal bauxites have been sampled along the strike (Karapetov and others, 1970). The 14 channel samples were chemically analyzed, and they showed an $\mathrm{Al}_{2} \mathrm{O}_{3}$ content that did not exceed $27 \mathrm{wt} \%$. The occurrence does not represent any potential interest because of the low $\mathrm{Al}_{2} \mathrm{O}_{3}$ content (Karapetov and others, 1970).

\section{Tangi Bauxite Occurrence}

Tangi bauxite occurrence is located in Zabul Province (32 $45^{\prime}$ N., $67^{\circ} 25^{\prime}$ E.; figs. 2 and 3). Several lens-shaped bauxite bodies have been identified in the base of the Chohan Formation overlying the Proterozoic through Cambrian Zargaran Formation. Bodies 5 to $70 \mathrm{~m}$ long and 1 to $15 \mathrm{~m}$ thick were sampled. The bauxite is massive, either ferruginous, greenish-gray bauxite with a small amount of pisolites or brown, cryptocrystalline bauxite. The $\mathrm{Al}_{2} \mathrm{O}_{3}$ content varies from 11.57 to $46.72 \mathrm{wt} \%$, and the $\mathrm{SiO}_{2}$ content from 11.28 to $66.79 \mathrm{wt} \%$ (Karapetov and others, 1970). 


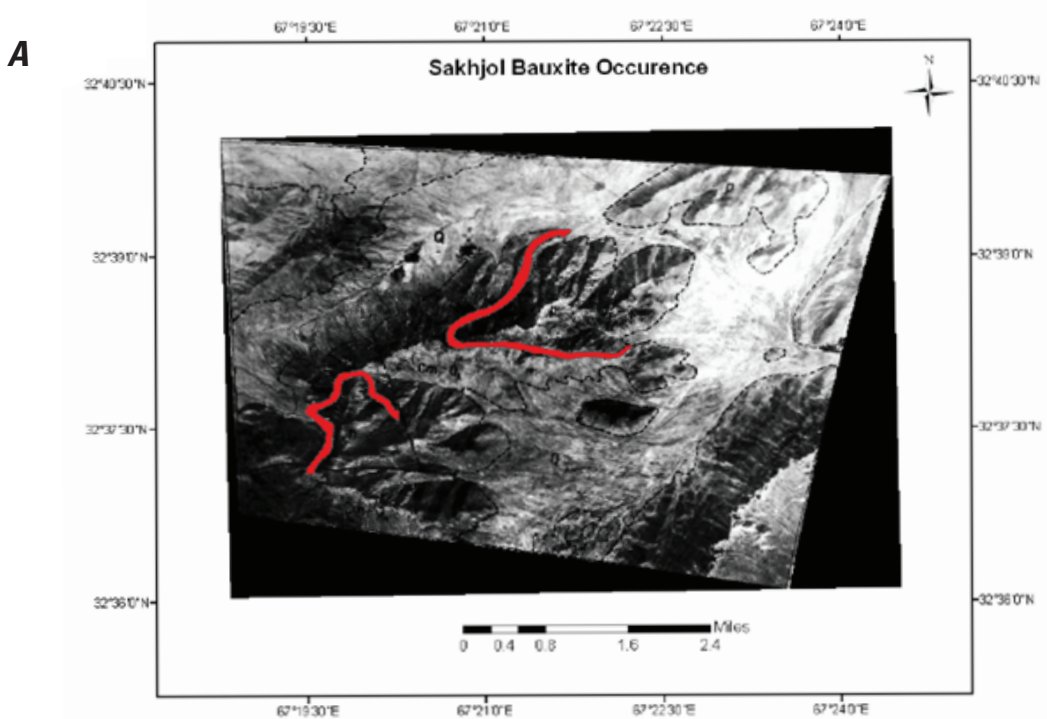

B

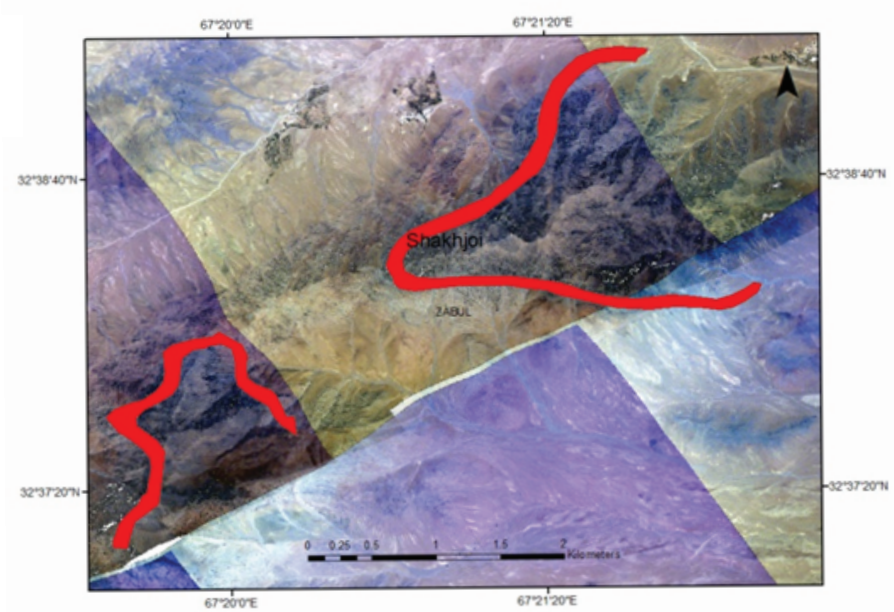

C

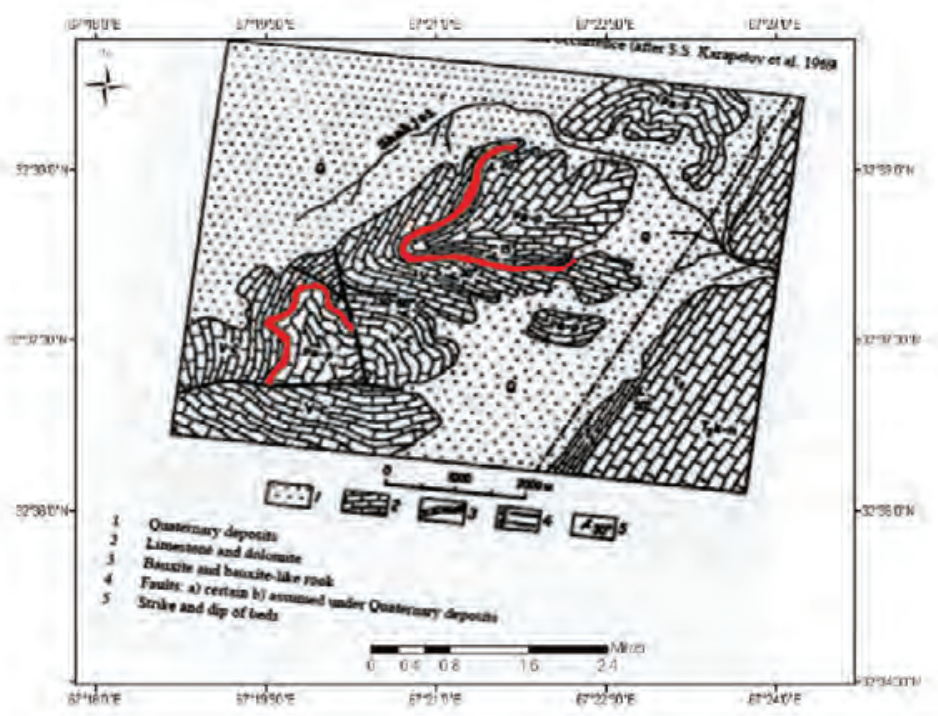

Figure 9. Sokhjoi bauxite occurrence, Arghandab block, Zabul Province; red polygons represent bauxite occurrences. $A$, Aerial photograph (Karapetov and others, 1970). $B$, Image provided by the U.S. Naval Research Laboratory. C, Geologic map (Abdullah and others, 2008). 


\section{Kandahar Province, Arghandab and Tirin Blocks}

Jurassic bauxites of the Vargach Formation have been discovered in many areas of the southern part of the Arghandab and Tirin blocks in the Obatu Sheila River Basin and in the region of Tanachay village, including Obatu Sheila I, II, and III, Surkhbet (I and II), Zamto-Kalay, Tor Ghar, Archa Ghar, and Surkhob. The Vargach Formation is composed of terrigenous and carbonate rocks 200 to $350 \mathrm{~m}$ thick. The Vargach Formation is divided into two subdivisions. The lower subdivision consists of irregular interlayers of siltstone, limestone, arenaceous limestone, calcareous sandstone, and quartz-feldspar sandstone and conglomerate. The green to rusty-red bauxitic rocks and bauxite are present at the base of the lower subdivision. The subdivision is 20 to $130 \mathrm{~m}$ thick. The Vargach lower subdivision was deposited on the eroded surface of Paynawa Limestone. The contact between the lower and upper subdivisions is a sharp transition from carbonate-terrigenous deposits of the lower subdivision into carbonates of the upper subdivision. The lower subdivision of Vargach Formation has been described from a section $7 \mathrm{~km}$ to the northeast of Sah Karez village, on the northern slope of Vargach Ridge. The section of this lower subdivision is as follows (Dovgal and others, 1970):

\begin{tabular}{|c|c|c|}
\hline Bed & Description & $\begin{array}{c}\text { Thickness } \\
\text { (meters) }\end{array}$ \\
\hline 11 & $\begin{array}{l}\text { Irregular interbeds }(1-2.5 \mathrm{~m}) \text { of sandstones and limestone. The limestone dominates. Quartz feldspar sand- } \\
\text { stones are fine-grained, pinkish-gray and gray. Dark-gray, almost black limestone is laminated at the upper } \\
\text { horizon and is arenaceous. }\end{array}$ & 22 \\
\hline 10 & Gray and ash-gray siltstone. & 3 \\
\hline 9 & Fine-grained, pinkish-gray calcareous sandstone. & 4 \\
\hline 7 & Fine-feldspar, laminated, pinkish-gray and gray sandstone. & 4 \\
\hline 6 & Ash-gray siltstone with red coating at the surface $(0.5 \mathrm{~m})$. & 2 \\
\hline 5 & Fine-grained, laminated, pinkish-gray quartz-feldspar sandstone. & 2.5 \\
\hline 4 & Reddish-gray and gray siltstone. & 5 \\
\hline 1 & Dark-green, pisolitic bauxites. Pisolites occupy $20-30 \%$ of the rock volume (size varies from 0.2 to $0.6 \mathrm{~cm}$ ). & 3 \\
\hline
\end{tabular}

The upper subdivision of the Vargach Formation lies conformably on the lower subdivision. The total thickness of the lower subdivision is $22 \mathrm{~m}$. The entire thickness of the section is $63 \mathrm{~m}$.

The lower subdivision of the Vargach Formation varies greatly over short distances. For instance, the lower subdivision in the Vargach Ridge area consists of terrigenous deposits, 25 to $130 \mathrm{~m}$ thick. In Tangay and Alim villages, the lower subdivision also consists of terrigenous deposits but is consistently thicker (120 to $140 \mathrm{~m}$ ). Near Surkhbet village, the lower subdivision consists mostly of carbonate rocks, 20 to $100 \mathrm{~m}$ thick (Dovgal and others, 1971).

Bauxite and bauxitic rocks at the bottom of the lower subdivision appear as continuous beds on the eroded and slightly karsted limestone surface of the Middle through Upper Jurassic Paynawa Limestone. The contact between lower subdivision of Vargach Formation and Paynawa Limestone is sharp, uneven, and wavy (fig. 10). This uneven surface is responsible for the variable thickness of the bauxite beds from 1 to $10 \mathrm{~m}$. The beds are composed of clayey, sandy bauxites; clayey bauxites; and lens-shaped bauxites. Sandstone and conglomerate are interbedded with the bauxitic beds. The bauxite-bearing rocks grade upward into sandstone and siltstone (Dovgal and others, 1971).

The bauxite and bauxitic rocks are traceable within an area of several tens of square kilometers. The horizon comprises lenses and sheet-like bodies of bauxite and bauxitic rocks, described by the Soviet workers (Karapetov and others, 1970) as clayey bauxite and clayey, sandy bauxite: these mixtures are predominant over pure bauxite. The bauxite lenses and interbeds are up to $250 \mathrm{~m}$ long and $6 \mathrm{~m}$ thick. The bauxite and bauxitic rock are interlayered and show gradual transitions and thus can only be clearly identified by chemical analysis (Karapetov and others, 1970).

The bauxitic horizons are subhorizontal and contain branching folds that plunge $20^{\circ}$. The bauxitic interval in this formation is continuous. The structure and geometry of the ore is complicated by a high degree of faulting. The faulting strikes northeast, but locally the faults strike northwest and are near vertical (Karapetov and others, 1970). 


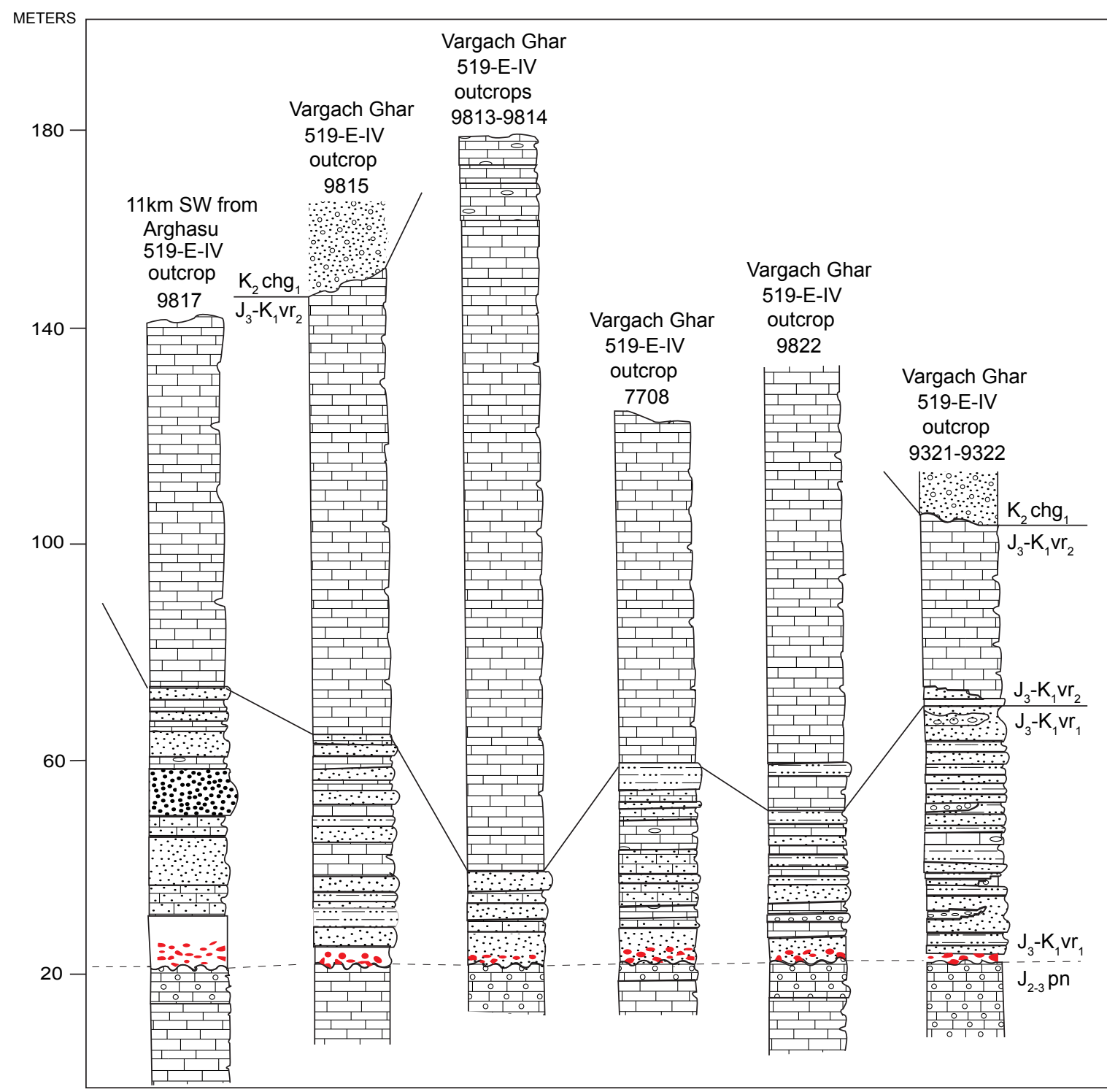

\section{EXPLANATION}

NOT TO SCALE

$\therefore$ Dark-green, pisolitic. Pisolites occupy $20-30 \%$ of the rock volume (size varies from $0.2-0.6 \mathrm{~cm}$ )

$\left.\begin{array}{c:c}0 \\ \hdashline\end{array}\right]$ Quartz-feldspar sandstone (Jurassic-Cretaceous Lower Subdivision)—-thin-grained, massive, pinkish-gray

$\cdots \cdots \cdot$ Siltstone (Jurassic-Cretaceous Lower Subdivision) — rusty-gray and gray, ash-gray

Clastic sandstone (Jurassic-Cretaceous Lower Subdivision)—composed of quartz andf eldspar

$\because \quad$ Limey sandstone (Jurassic-Cretaceous Lower Subdivision)—fine-grained, pinkish-gray

Platy limestone (Jurassic Upper Subdivision)—bioclastic-detrital, dark-gray and rusty-brown

Conglomerate (Cretaceous Lower Subdivision of Chagai Formation)—-medium to fine-grained, gray color with violet tint. Pebbles composed of gniess and crystalline schists, migmatite, aphibolite, diabase, phyllites, polimictic sandstones and siltstones; well sorted and rounded, in places shingled

Limestone (Jurassic-Cretaceous Lower Subdivision)—massive, gray with scarce amount of pebbles of other material

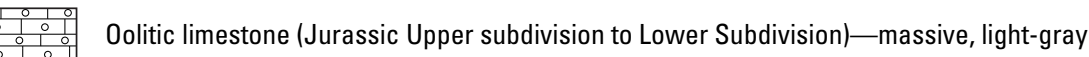

Figure 10. Correlation of Vargach Formation in the Tirin block, Kandahar Province (from Dovgal and others, 1971); pisolitic bauxite highlighted in red. 


\section{Obatu Sheila Bauxite Deposit}

The Obatu Sheila bauxite deposit (31 $58^{\prime} 31^{\prime \prime}$ N., 66 $12^{\prime} 30^{\prime \prime}$ E. and $32^{\circ} 02^{\prime} 58^{\prime \prime}$ N., 66 $21^{\circ} 54^{\prime \prime}$ E.) is the largest known deposit and includes bauxite bodies I, II, and III (fig. 11). The area lies in the syncline of the Sar-e-Koh Mountain, which is 2,500 $\mathrm{m}$ high. The reserves of the resource is 7,247,000 tons (table 6) (Han, 1964).

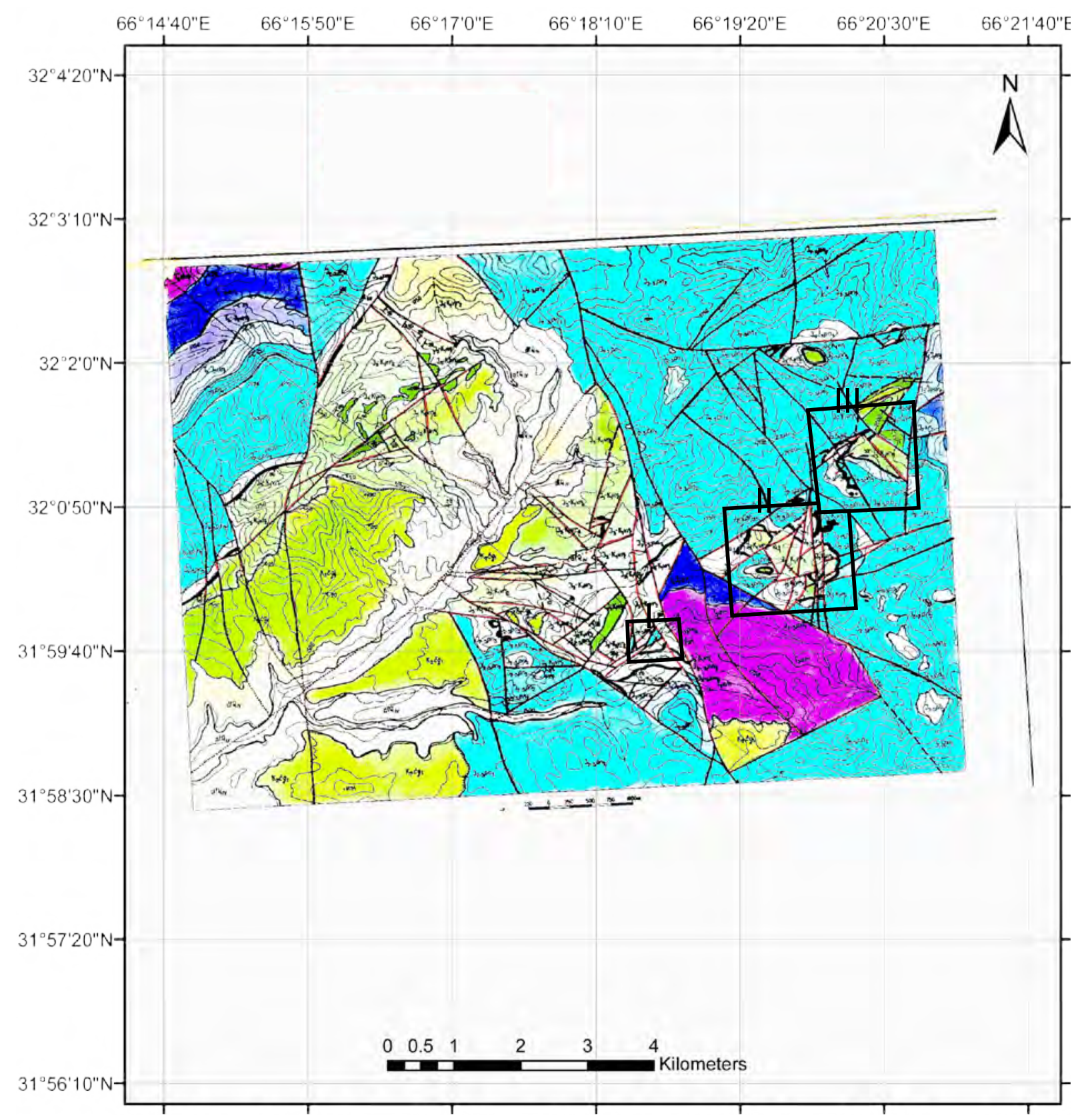

Figure 11. Structural map of the Obatu Sheila bauxite deposit. Red boxes and numbers indicate the location of Obatu Sheila I, II, and III (modified from Dovgal and others, 1971).
Table 6. Total reserves of the Obatu Sheila bauxite deposit (Han, 1964).

\begin{tabular}{lc}
\hline \multicolumn{1}{c}{ Ore reserves of the Obatu Sheila deposit } & Tons \\
\hline Minable ore by open-casting & $1,322,000$ \\
Extension of the above as probable ore reserves & $5,925,000$ \\
Total & $\mathbf{7 , 2 4 7 , 0 0 0}$ \\
\hline
\end{tabular}


The Obatu Sheila bauxite deposit is about $80 \mathrm{~km}$ from Shah-Kharez to the north of Kandahar City. The altitude of the area is from 1,600 to 2,000 m above sea level. The most intensively studied part of the Obatu Sheila bauxite deposit was Obatu Sheila II (fig. 12). The bauxite body in this area has been sampled in 13 trenches, 5 pits, and 95 channels (fig. 13).

Jurassic rocks and the base of the Early Cretaceous rocks are highly dislocated and folded by an Early Cretaceous orogeny. Bauxite is present in lens-shaped and lenslike interbeds, extends as far as $250 \mathrm{~m}$, and is as much as 5 to $6 \mathrm{~m}$ thick. According to X-ray diffraction analysis by Mitsui Central Laboratory in Tokyo (Horita and others, 1971, unpublished laboratory report), the primary bauxite mineral in the Obatu Sheila deposit is diaspore.

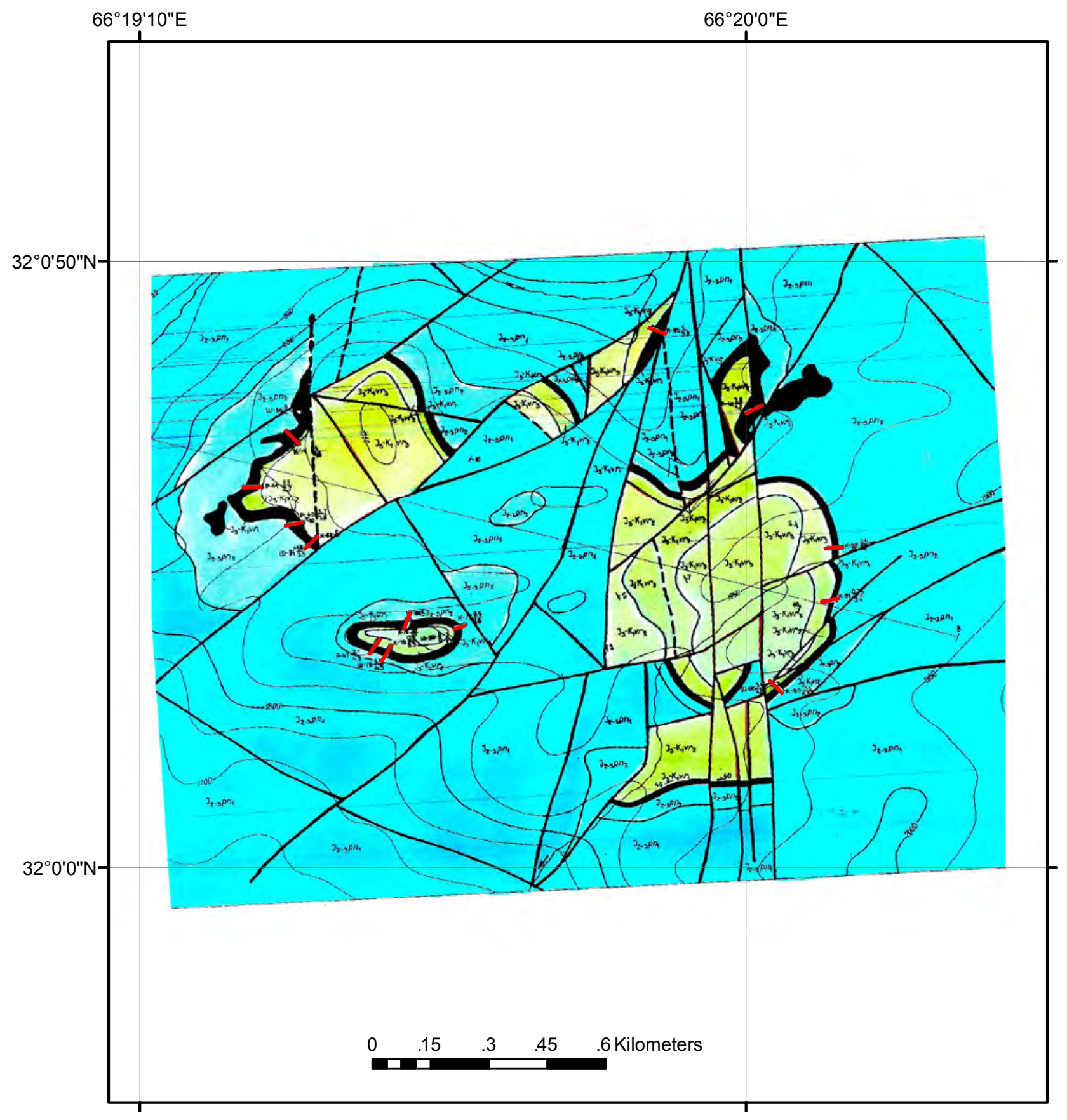

Figure 12. Schematic geologic map of Obatu Sheila II exposed ore, Kandahar Province; red lines mark trenches (modified from Dovgal and others, 1971). 
Soviet geologists studied and mapped the Obatu Sheila deposit in detail. The first type of bauxite at Obatu Sheila is karst-type bauxite that is concentrated in karst holes, fissures, and cavities on the surface of Jurassic limestone of the Paynawa Limestone. The bauxites are underlain by conglomerate containing sharp, angular fragments and blocks of limestone, and these are overlain by sandy, clayey bauxite that contains no pisolites.

The second type of bauxite at Obatu Sheila appears as "hanging" bodies of bauxite between bauxitic rocks. The "hanging" body of bauxite comes in contact in some places with the weathered and karsted surface of limestone of the Paynawa Limestone. This deposit is in a graben that occurred as a result of multiple faulting. The height is approximately $2,000 \mathrm{~m}$. Outwardly, the bauxite is dense and massive, exhibits conchoidal fracture, and is pisolitic, 1 to $5 \mathrm{~m}$ thick. The color of bauxite is mainly green and red-brown; however, dark-gray, gray, and lilac colors were also observed. The pisolites ( 0.5 to $1 \mathrm{~cm}$ in diameter) are composed of aluminum oxide (including diaspore or boehmite), exhibit concentric-wavy texture, and constitute 50 to $85 \mathrm{wt} \%$ of bauxite. The $\mathrm{Al}_{2} \mathrm{O}_{3}$ content in the bauxite of area II varies from 45 to $50 \mathrm{wt} \%$, and $\mathrm{SiO}_{2}$ content is from 2 to $4.5 \mathrm{wt} \%$. Accumulation of muscovite has also been observed. The pisolites are cemented by mixtures of hydromica, ferric oxide hydrates, and alumina and contain quartz fragments, rutile, and zircon. In places, only boehmite and diaspore are present (Dovgal and others, 1971).

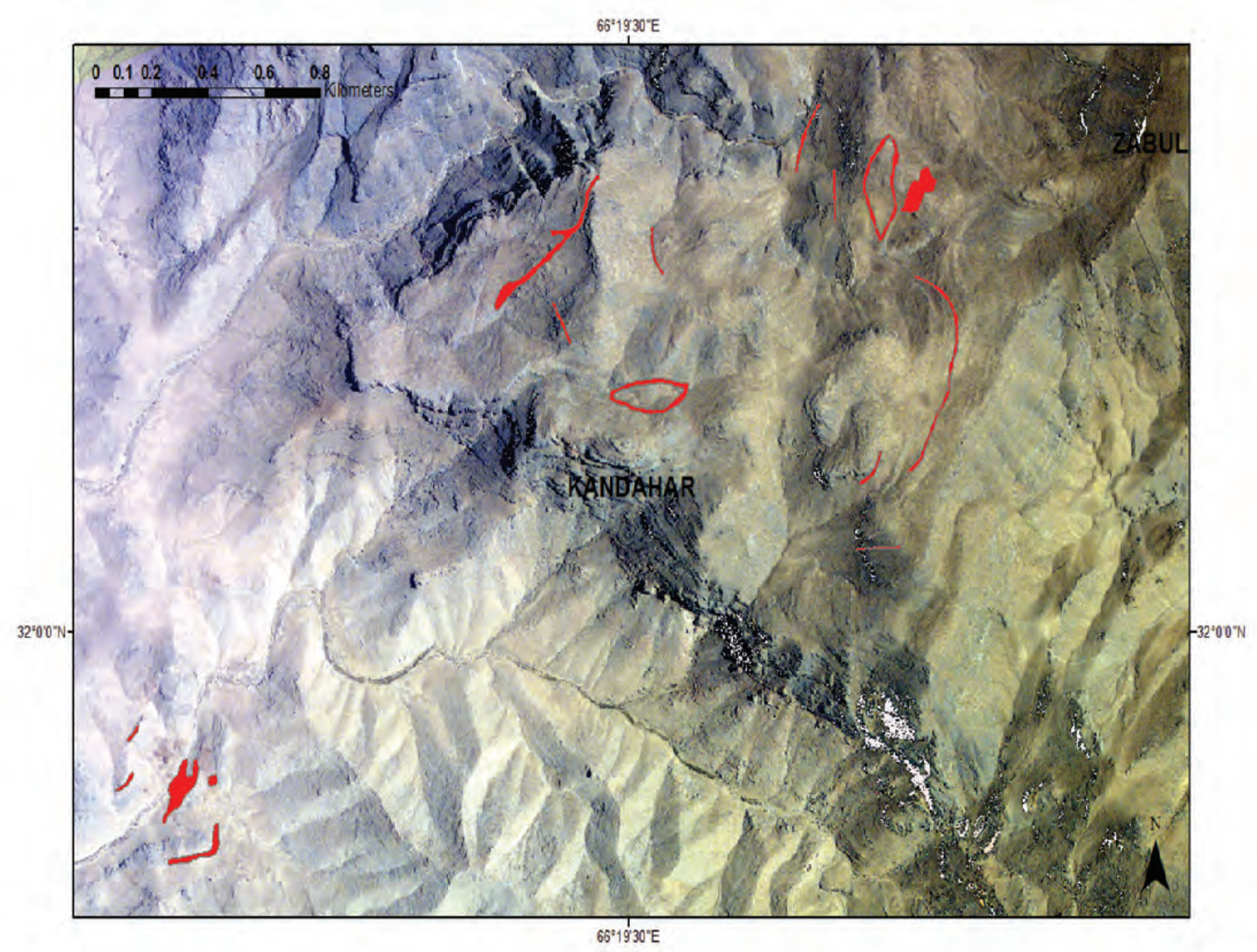

Figure 13. Map of ore-reserves calculation for the Obatu Sheila bauxite deposit in Kandahar Province (derived from Dovgal and others, 1971, and shown in red) placed on photography taken by U.S. Naval Research Laboratory in 2006 and 2008. 
The third type of bauxite at Obatu Sheila is confined to a folded (pleated) zone, which is the eastern wing of an anticline (graben-synclinal structure) in the center of a synclinal fold. The height varies from 2,000 to 2,500 $\mathrm{m}$. This zone was not studied in detail. The major chemical components of the bauxite are listed in tables 7 and 8 below. The $\mathrm{Al}_{2} \mathrm{O}_{3}$ range is from 27 to $54 \mathrm{wt} \%$. The clayey bauxite contains from 15 to $35 \mathrm{wt} \%$ of $\mathrm{Al}_{2} \mathrm{O}_{3}$, and pisolites compose approximately $50 \mathrm{wt} \%$ of the rock (tables 7 and 8; Dovgal and others, 1971).

The bauxites contain from 42 to $58 \mathrm{wt} \% \mathrm{Al}_{2} \mathrm{O}_{3}$, from 12 to $20 \mathrm{wt} \% \mathrm{SiO}_{2}$, between 12 and $20 \mathrm{wt} \% \mathrm{Fe}_{2} \mathrm{O}_{3}, 0.03 \mathrm{wt} \%$ of $\mathrm{TiO}_{2}, 12 \mathrm{wt} \%$ of ignition loss, and the $\mathrm{Al}_{2} \mathrm{O}_{3}: \mathrm{SiO}_{2}$ ratio varies between 2.7 and 6.8. The speculative reserves of the industrial grade bauxite are 30 to 35 million tonnes (Dovgal and others, 1971). Samples with less than $42 \mathrm{wt} \% \mathrm{Al}_{2} \mathrm{O}_{3}$ are considered clayey or sandy clayey bauxites or bauxitic rocks (with very low alumina percentage) (Dovgal and others, 1971).

Even though the Obatu Sheila bauxite deposit is estimated to be several million tons, there are several issues that may impede development, such as (1) mountainous location, (2) lack of industrial water, (3) shape of ore bodies, which would require underground mining, and (4) mineral character of bauxite, consisting of diaspore and boehmite rather than gibbsite (Dovgal and others, 1971).

Table 7. Chemical analysis for Obatu Sheila I (modified from Dovgal and others, 1971).

[ID, identifier; m, meter]

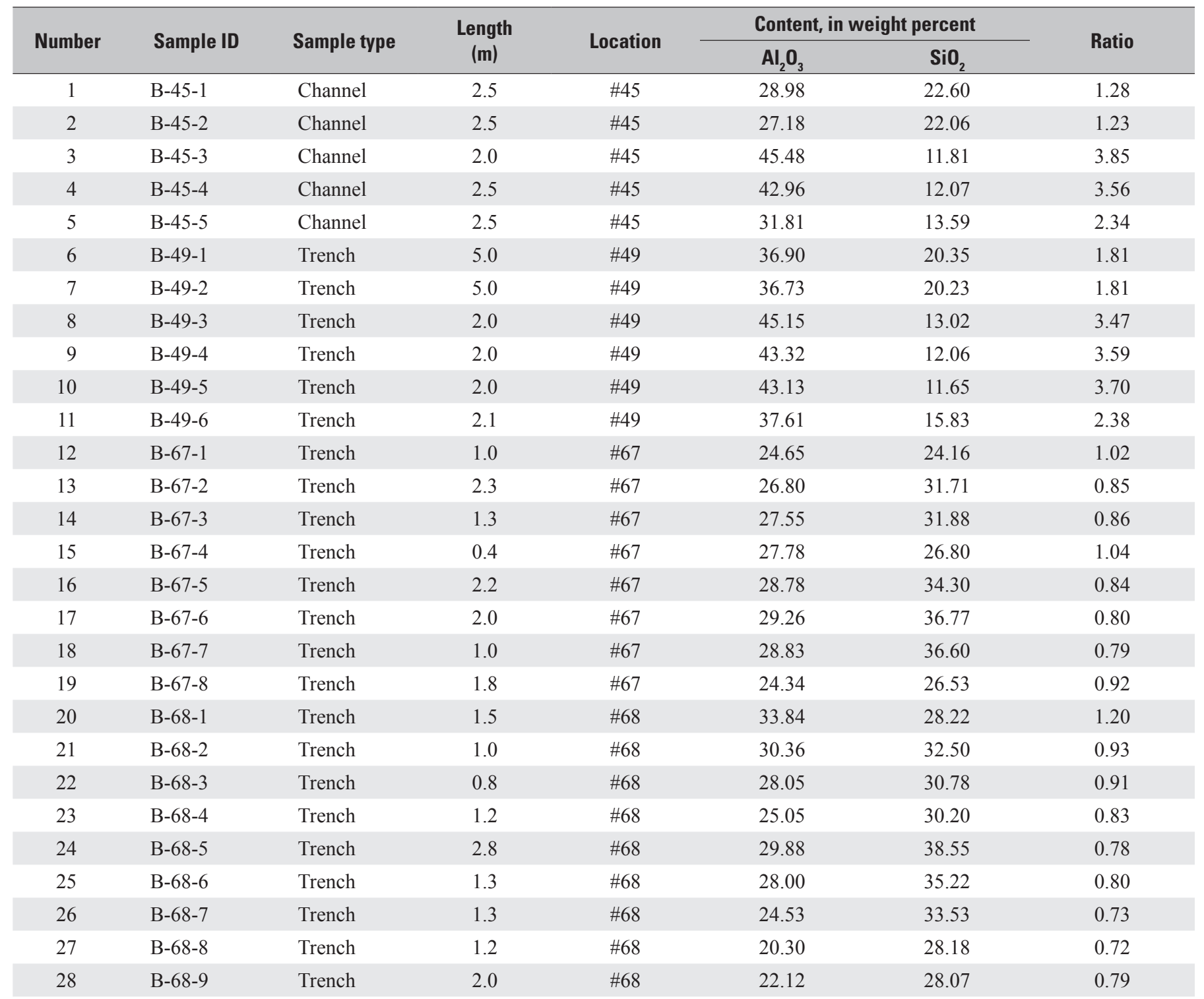


Table 7. Chemical analysis for Obatu Sheila I (modified from Dovgal and others, 1971)._- Continued [ID, identifier; m, meter]

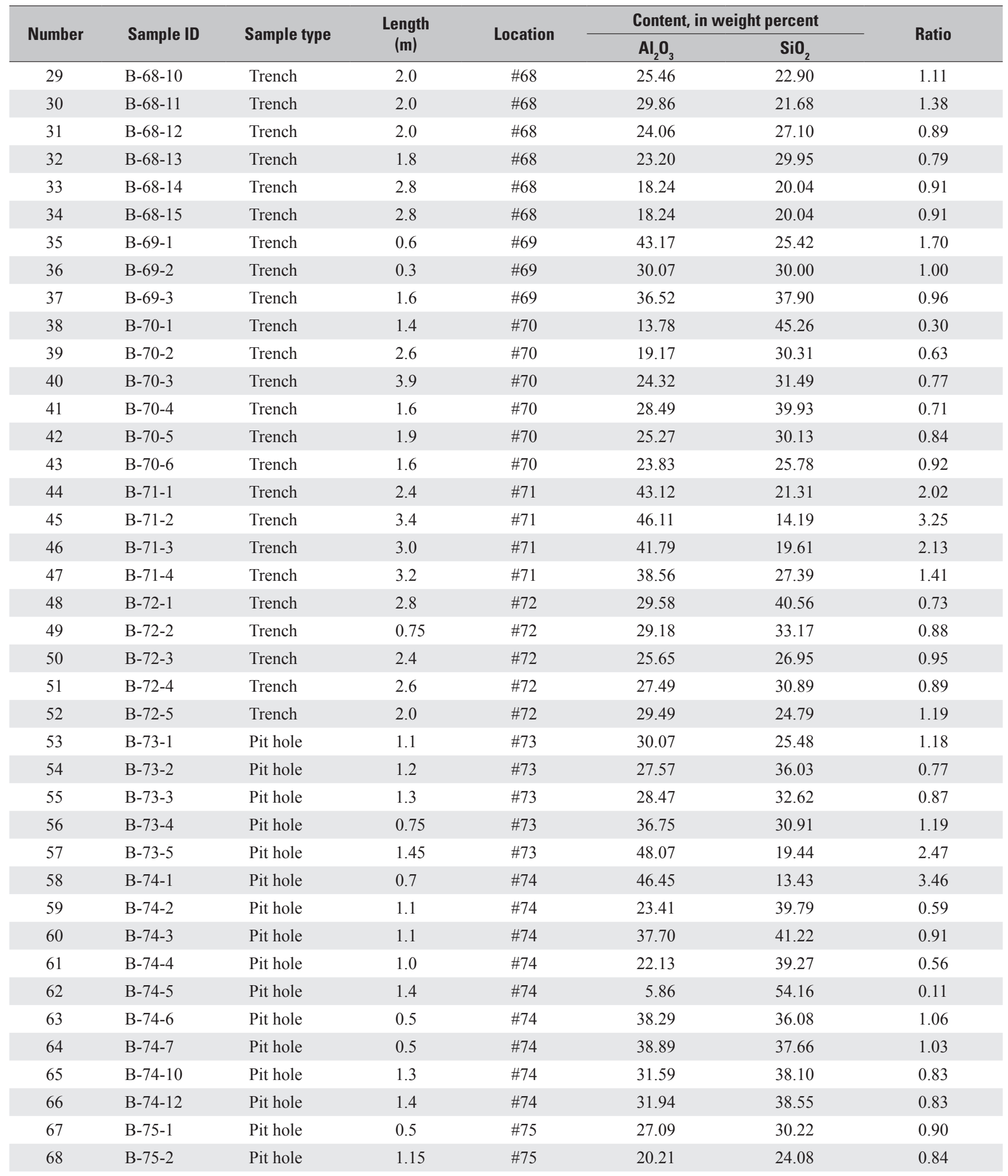


Table 7. Chemical analysis for Obatu Sheila I (modified from Dovgal and others, 1971).—Continued [ID, identifier; m, meter]

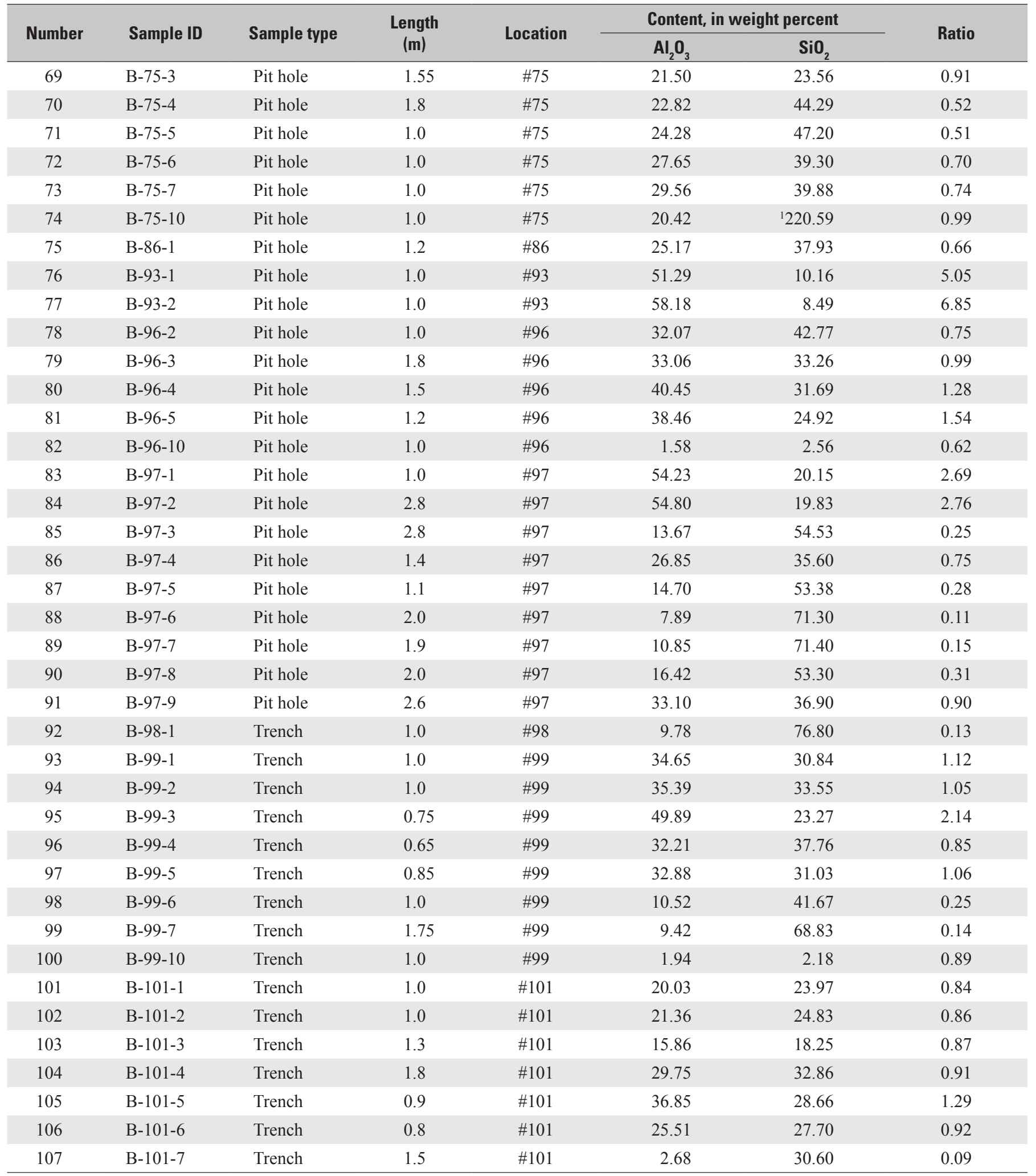

${ }^{1}$ This value was obviously erroneous in the source document. The actual value is likely either 20.59 or $22.59 \mathrm{wt} \%$. 
Table 8. Chemical analysis for Obatu Sheila II and III (modified from Dovgal and others, 1971).

[ID, identifier; m, meter]

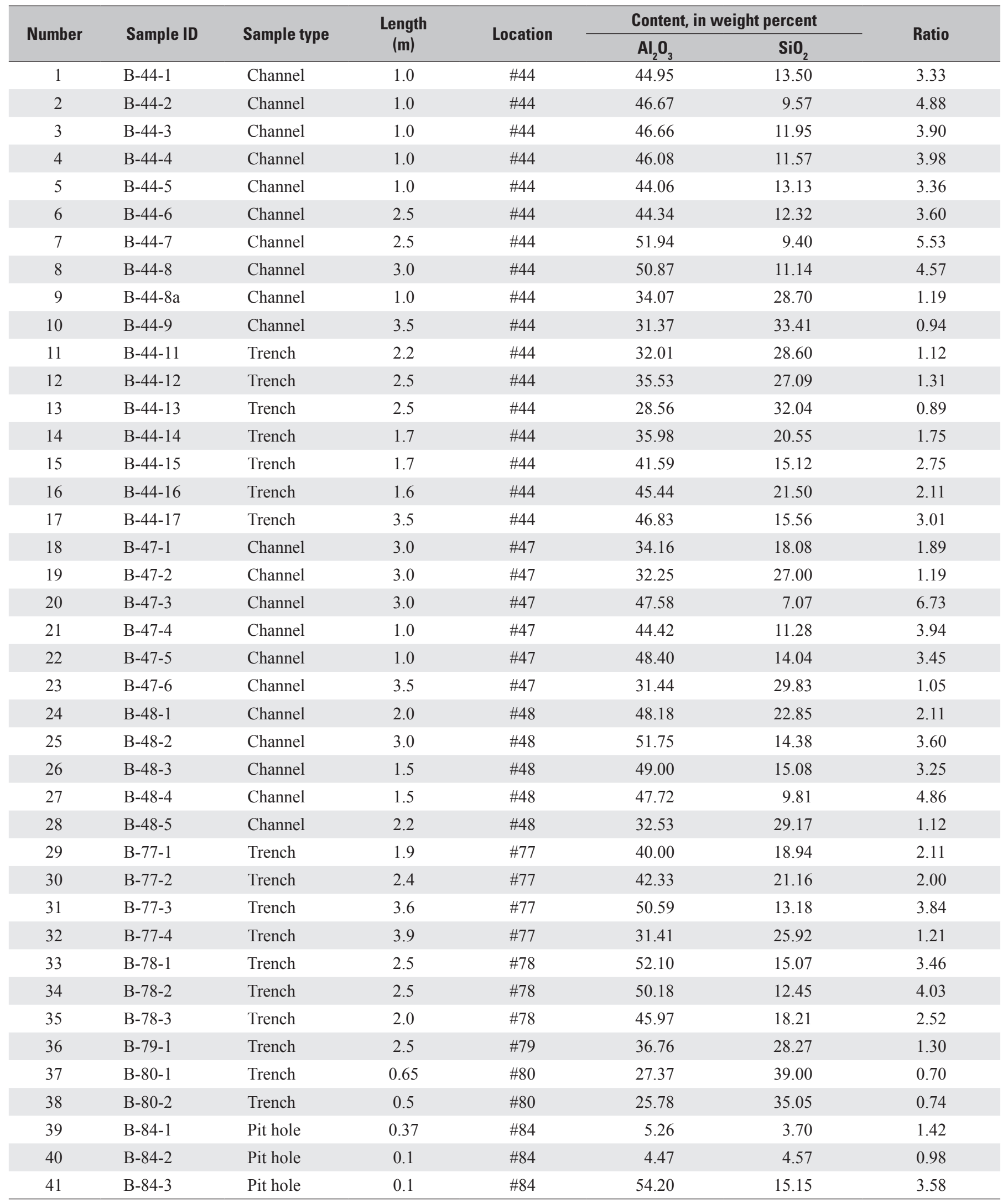




\section{Tor Ghar Bauxite Deposit}

The Tor Ghar bauxite deposit (Abdullah and others, 2008; Dovgal and others, 1971; 32 $155^{\prime} 44^{\prime \prime}$ to $32^{\circ} 18^{\prime} 19^{\prime \prime}$ N., $66^{\circ} 00^{\prime} 19^{\prime \prime}$ to $66^{\circ} 03^{\prime} 07^{\prime \prime}$ E.) is within the Sekhab-Zamto Kalay subarea as shown in figure 14. The development area of productive bauxitic deposit of Vargach Formation is $8 \mathrm{~km}^{2}$. The bauxite-bearing layer is 3.5 to $4.0 \mathrm{~m}$ thick along the strike and extends $1.5 \mathrm{~km}$. The bauxite-bearing rocks are greenish gray and stony. Chemical analysis of three composite ore samples from bauxitic rocks yielded variable alumina and silica content: $\mathrm{Al}_{2} \mathrm{O}_{3}, 10.6$ to $58 \mathrm{wt} \%$; $\mathrm{SiO}_{2}, 42.71$ to $69.77 \mathrm{wt} \%$ (Dovgal and others, 1971).

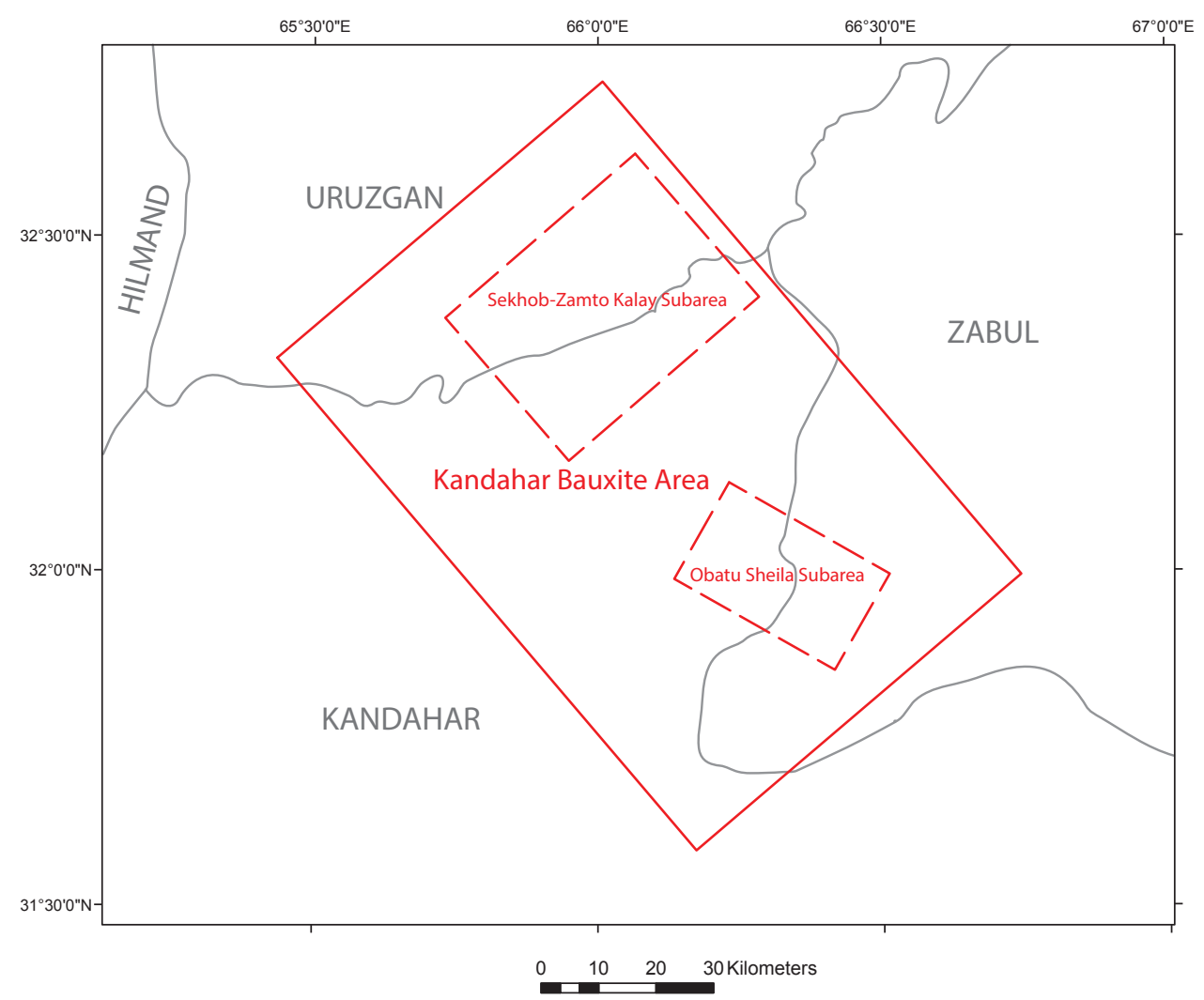

Figure 14. Location of Kandahar Bauxite Area and subareas in Kandahar, Uruzgan, and Zabul Provinces (from Abdullah and others 2008; Dovgal and others, 1971).

\section{Archa Ghar Bauxite Deposit}

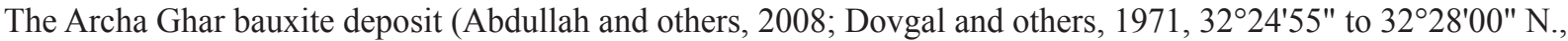
$66^{\circ} 12^{\prime} 02^{\prime \prime}$ to $66^{\circ} 09^{\prime} 28^{\prime \prime}$ E.) is on the southeastern slope of the Archa Ghar Ridge, also within the Sekhab-Zamto Kalay subarea as shown in figure 14. The developed area of productive bauxitic deposits is $3.0 \mathrm{~km}^{2}$. The thickness of the bauxite-bearing layer is 2.5 to $8 \mathrm{~m}$ along the strike and extends as far as $4.0 \mathrm{~km}$ (based on aerial photography). The bottom of the layer (0.5 to $2.0 \mathrm{~m}$ ) contains pisolitic, brown-, claret-, and green-colored bauxite-bearing rocks with clayey cement. The amount of pisolites is 10 to $15 \mathrm{wt} \%$ of the rock mass. The top part of the layer $(2.0$ to $6.0 \mathrm{~m})$ contains bauxite-bearing sandstone and conglomerate

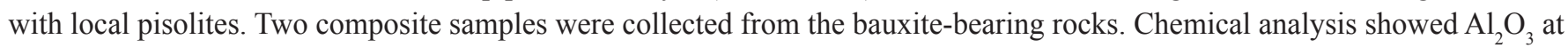
7.95 to $23.62 \mathrm{wt} \%$ and $\mathrm{SiO}_{2}$ at 10.87 to $28.30 \mathrm{wt} \%$ (Dovgal and others, 1971).

\section{Zamto Kalay Bauxite Deposit}

The Zamto Kalay bauxite deposit (Abdullah and others, 2008; Dovgal and others, 1971; 32²2'19" to 32²3'26" N., $66^{\circ} 10^{\prime} 06^{\prime \prime}$ to $66^{\circ} 08^{\prime} 42^{\prime \prime}$ E.; fig. 14) is $2 \mathrm{~km}$ to the northwest from Zamto Kalay village. The area of productive bauxitic deposits of Vargach Formation is $1.7 \mathrm{~km}^{2}$. The bauxite-bearing layer is 7.5 to $10 \mathrm{~m}$ thick along the strike and extends as far as $0.6 \mathrm{~km}$. Bauxite-bearing rocks are greenish-gray, stony, and pisolitic. The bottom of the layer (1.5 to $4 \mathrm{~m}$ ) is composed of bauxitebearing rocks with 10 to $15 \mathrm{wt} \%$ of pisolites cemented by clay cement. The top of the layer (approximately $6.0 \mathrm{~m}$ ) contains sandstones with scarce pisolites. The bauxite-bearing rocks were not sampled in this area (Dovgal and others, 1971). 


\section{Uruzgan Province, Tirin Block}

\section{Surkhbet Bauxite Deposits}

The Surkhbet bauxite area consists of two deposits, Surkhbet I and Surkhbet II, which are $50 \mathrm{~km}$ from Tirin and $130 \mathrm{~km}$ from Kandahar, at 2,000 m altitude, in Uruzgan Province. The area is mountainous, with moderate relief and large lowlands. Water resources are scarce in this area. The ridge between Tanachou and Surkhbet plains, as shown in figure 15 (Dovgal and others, 1971).

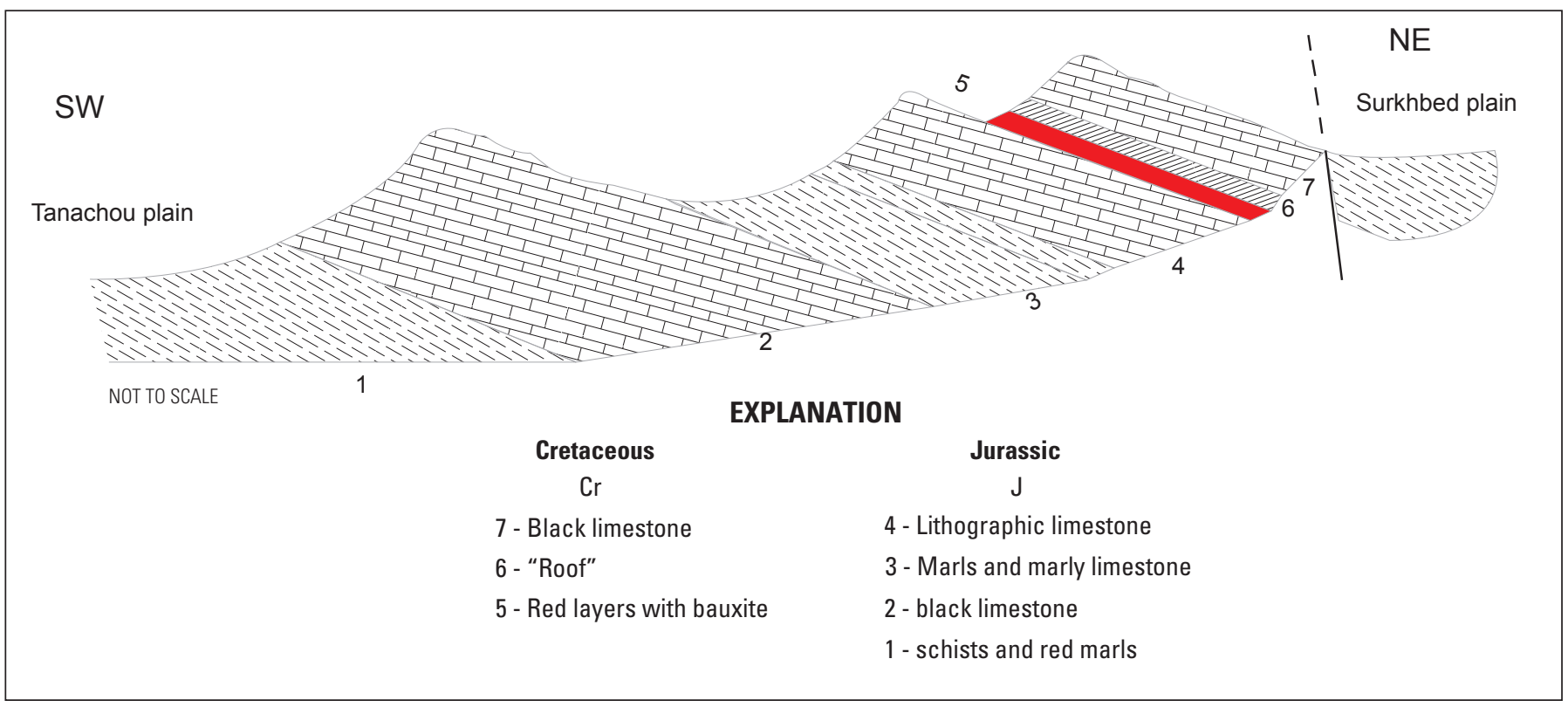

Figure 15. Profile of section of Surkhbet bauxite deposit in Uruzgan Province (modified from Lapparent, 1969).

The Surkhbet I bauxite deposit (Abdullah and others, 2008; Dovgal and others, $1971 ; 32^{\circ} 20^{\prime} 11^{\prime \prime}$ to $32^{\circ} 22^{\prime} 50^{\prime \prime}$ N., $66^{\circ} 03^{\prime} 21^{\prime \prime}$ to $66^{\circ} 01^{\prime} 18^{\prime \prime}$ E.) is within the Sekhob-Zamto Kalay subarea as shown in figure 14 and is $2 \mathrm{~km}$ to the south from Surkhbet village. The area of productive deposits for bauxite is 3 to $4 \mathrm{~km}^{2}$. The bauxite-bearing layer is 1 to $3 \mathrm{~m}$ thick along the strike and extends as far as $6 \mathrm{~km}$. Bauxite-bearing rocks are greenish gray, greenish-olive black and claret red, stony, and pisolitic. The rocks are made up of 15 to $30 \mathrm{vol} \%$ pisolites ( 2 to 10 millimeters $[\mathrm{mm}]$ in diameter). The top of the layer is eroded, and bauxite-bearing rocks are included as fragments in the overlying limestone. Two composite samples were collected from bauxite-bearing rocks. The chemical analysis showed $\mathrm{Al}_{2} \mathrm{O}_{3}$ from 19.04 to $27.96 \mathrm{wt} \%$ and $\mathrm{SiO}_{2}$ from 19.08 to $28.36 \mathrm{wt} \%$ (Dovgal and others, 1971).

The description of beds by Lapparent (1969) is modified here as follows (chemical analyses from Lapparent, 1969, are in table 9):

\begin{tabular}{cl}
\hline Bed & \multicolumn{1}{c}{ Description } \\
\hline 7 & Massive recrystallized black limestone with corals and other fossil remains. \\
\hline 6 & Black limestone beds. \\
\hline 5 & Brecciated white felsic rhyolite that is present throughout the syncline. \\
\hline 4 & $\begin{array}{l}\text { Cretaceous red conglomerates with angular Jurassic limestone blocks. This unit thickens from northeast to southwest and is } \\
\text { apparently concordant with the bauxite-bearing beds below. }\end{array}$ \\
\hline $3 \mathrm{~d}$ & Black limestone. \\
\hline $3 \mathrm{c}$ & Beds with ripple marks. \\
\hline $3 \mathrm{~b}$ & Yellowish limestone. \\
\hline $3 \mathrm{a}$ & Black calcareous limestone with traces of aluminum. \\
\hline 2 & Red sand with calcareous limestone and pisolitic bauxite. \\
\hline 1 & Early Jurassic, calcareous white and red lithology, forms cliff. The surface of the Early Jurassic layer is corroded and is iron stained. \\
\hline
\end{tabular}


Table 9. Analysis of three samples from the Surkhbet bauxite deposit (from Lapparent, 1969).

\begin{tabular}{crrrcc}
\hline Loss on ignition & $\mathbf{A l}_{2} \mathbf{O}_{3}$ & $\mathbf{S i O}_{2}$ & $\mathbf{F e}_{2} \mathbf{O}_{3}$ & $\mathbf{T i O}_{2}$ & $\mathbf{C a 0}$ (carbonate) \\
\hline 23.90 & 9.90 & 9.60 & 27.80 & 0.50 & 28.00 \\
7.70 & 38.00 & 37.80 & 10.80 & 2.10 & Traces \\
14.80 & 17.50 & 16.80 & 34.00 & 1.30 & 15.60 \\
\hline
\end{tabular}

The Surkhbet II bauxite deposit (Abdullah and others, 2008; Dovgal and others, 1971; 32²2'29" to $32^{\circ} 23^{\prime} 14^{\prime \prime}$ N., $66^{\circ} 04^{\prime} 18^{\prime \prime}$ to $66^{\circ} 03^{\prime} 49^{\prime \prime}$ E., figs. 14 and 16) is $1.5 \mathrm{~km}$ to the east of Surkhbet village. The area of productive bauxitic deposits is $0.6 \mathrm{~km}^{2}$. The bauxite-bearing layer is 2 to $5 \mathrm{~m}$ thick along the strike and extends as far as $1.2 \mathrm{~km}$. The color, the texture, and the amount of pisolites are similar to those of bauxite-bearing rocks of the Surkhbet I bauxite deposit. The bauxite-bearing rocks were sampled by six composite samples. Chemical analysis showed $\mathrm{Al}_{2} \mathrm{O}_{3}$ from 12.0 to $38.32 \mathrm{wt} \%$ and $\mathrm{SiO}_{2}$ from 10.93 to $45.26 \mathrm{wt} \%$ (Dovgal and others, 1971).

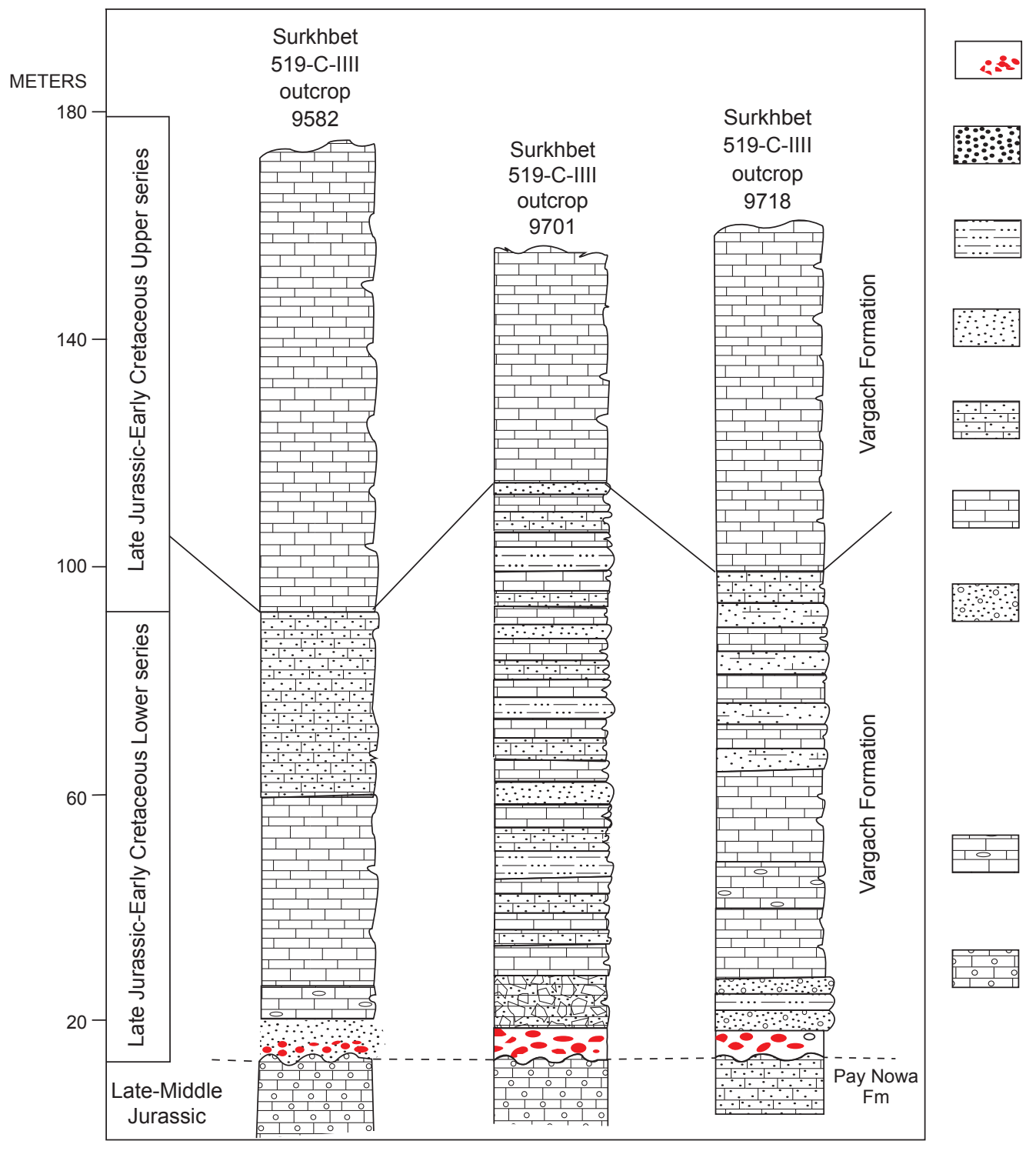

\section{EXPLANATION}

Dark-green, pisolitic. Pisolites occupy $20-30 \%$ of the rock volume (size varies from $0.2-0.6 \mathrm{~cm}$ )

Quartz-feldspar sandstone (JurassicCretaceous Lower Subdivision)thin-grained, massive, pinkish-gray

Siltstone (Jurassic-Cretaceous Lower Subdivision)—rusty-gray and gray, ash-gray

Clastic sandstone (Jurassic-Cretaceous Lower Subdivision) - composed of quartz and feldspar

Limey sandstone (Jurassic-Cretaceous Lower Subdivision)—fine-grained, pinkish-gray

Platy limestone (Jurassic Upper Subdivision)-bioclastic-detrital, dark-gray and rusty-brown

Conglomerate ( Cretaceous Lower Subdivision of Chagai Formation)medium to fine-grained, gray color with violet tint. Pebbles composed of gniess and crystalline schists, migmatite, aphibolite, diabase, phyllites, polimictic sandstones and siltstones; well sorted and rounded, in places shingled

Limestone (Jurassic-Cretaceous Lower Subdivision) - massive, gray with scarce amount of pebbles of other material

Oolitic limestone (Jurassic Upper subdivision to Lower Subdivision)massive, light-gray

Figure 16. Correlation of Vargach Formation for Surkhbet deposits in Kandahar Province (from Dovgal and others, 1971). 


\section{Doubalagh Bauxite Deposit}

The Doubalagh area near Surkhbet deposit was visited and trenched by Technoexport engineers in November 1969. The dip is approximately $25^{\circ}$. The variation in facies was observed in the northern part of the valley. The red layer is approximately $15 \mathrm{~m}$ thick and contains red limestone, and bauxite is enriched in ferruginous pisolites (fig. 17). The ore appears in lenticular shape and of poor quality. It does not appear interesting from an industrial point of view (Dovgal and others, 1971).

\section{Sekhab Bauxite Deposit}

The Sekhab bauxite deposit (Abdullah and others, 2008; Dovgal and others, 1971; 32 $24^{\prime} 08^{\prime \prime}$ to $32^{\circ} 25^{\prime} 29^{\prime \prime} \mathrm{N}^{\prime}$., $65^{\circ} 55^{\prime} 59^{\prime \prime}$ to $65^{\circ} 58^{\prime} 11^{\prime \prime}$ E.) is $2.5 \mathrm{~km}$ east of Sekhab village. The area of productive bauxitic deposits is $3.0 \mathrm{~km}^{2}$. The basal bauxite bed is 0.8 to $1.0 \mathrm{~m}$ thick and contains bauxite fragments which grade along strike into dolomites and sandy limestone of rusty-claret and cherry color. The basal bauxite bed does not have any potential for high grade bauxite (Dovgal and others, 1971).

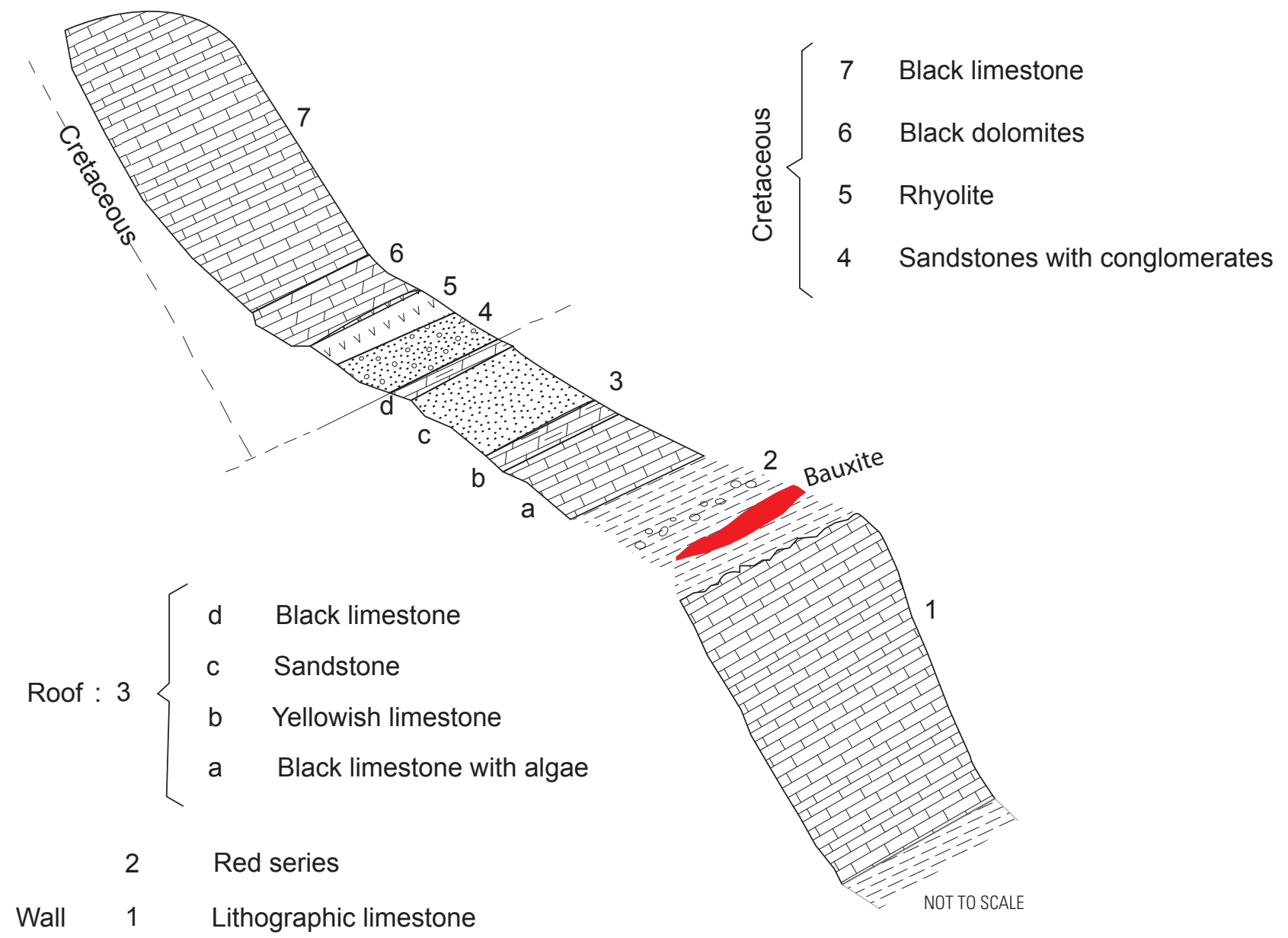

Figure 17. Detailed profile of Surkhbet and Doubalagh (modified from Lapparent, 1969). 


\section{Northern Afghanistan Platform}

The Northern Afghanistan Platform occupies the northern part of the country, beginning from Firuz-Koh to Hindukush Ridges, extending through Badakshan to the Amu-Dariya River, and ending in the southeast at the Hari Rod fault system. The platform is characterized by Hercinian folding and Jurassic to Paleogene sedimentary cover.

\section{Baghlan Province, Surkhob Zone}

\section{Tala Barfak (Nalag) Bauxite Occurrence}

The Tala Barfak (Nalag) bauxite occurrence (Abdullah and others, 2008; 35²5'16" N., 6809'20" E.) is slightly to the northwest from the Tala Wa Barfak village in Baghlan Province (figs. 2 and 3). The paleosol is developed on an erosion surface on Triassic volcanic rocks, is irregular in thickness, and is overlain by Lower Jurassic sediments. The lower part of the stratigraphic section is up to $5 \mathrm{~m}$ thick (usually 0.3 to $1.5 \mathrm{~m}$ ) and is a saprolite with altered ferruginous brown volcanic rocks. This altered saprolite is overlain by bleached, lumpy, dense clays. The clays are up to $5 \mathrm{~m}$ thick (usually $3 \mathrm{~m}$ ) and contain primary structure in places. The clays are overlain by dense foliated, lumpy, pisolitic bauxite (1.5 to $2 \mathrm{~m}$ thick), which is interbedded with pink, dense, limy bauxite, 0.6 to $1 \mathrm{~m}$ thick. The deposits are overlain by $0.5 \mathrm{~m}$ of gray, foliated, clayey bauxite with small pisolites (Sborshchikov and others, 1973).

The lower and middle part of the paleosol are enriched in silica and iron oxide. The aluminum oxide increases toward the top. The thickness of the alumina rich rocks does not exceed $3 \mathrm{~m}$. The bauxite occurs as at least 10 separate lenses at the top of the paleosol: each lense is as much as $4 \mathrm{~m}$ thick and as much as $200 \mathrm{~m}$ long (Sborshchikov and others, 1973).

The text of the report by Abdullah and others (2008) indicated that 18 samples enriched in aluminuim oxide were collected in this deposit and recorded in the table; however, the table is in the Russian version of the report, which is missing.

According to the $\mathrm{SiO}_{2}$ calculation, (1) two of the samples are referred to as low-iron sandy bauxites, (2) five of the samples are referred to as low-iron clayey bauxites, and (3) one sample (5138) with silicic modulus $\left(\mathrm{Al}_{2} \mathrm{O}_{3}: \mathrm{SiO}_{2}\right.$ ratio) 2.62 is bauxite of industrial grade (Sborshchikov and others, 1973). The gray to pink bauxite is pisolitic. The pisolites are 2 to $4 \mathrm{~mm}$ in diameter and consist of boehmite cemented by a mixture of cryptocrystalline kaolonite with boehmite. This bauxite bed is in the upper part of the paleosol and is overlain by Jurassic coal-bearing deposits. The lower part of the bed contains a bauxitic kaolinite. The bauxite contains $52.34 \mathrm{wt} \%$ alumina, $19.9 \mathrm{wt} \%$ silica, $16.5 \mathrm{wt} \%$ iron oxide, $1.4 \mathrm{wt} \%$ calcium oxide, and $0.75 \mathrm{wt} \%$ magnesium oxide, with the $\mathrm{Al}_{2} \mathrm{O}_{3}: \mathrm{SiO}_{2}$ ratio being 2.6. Chemical analyses of the other varieties of clayey rocks from the bauxitebearing unit suggest that these are partly low-iron, clayey bauxites with a 0.98 to $2.17 \mathrm{Al}_{2} \mathrm{O}_{3}: \mathrm{SiO}_{2}$ ratio and partly low-iron, sandy bauxites with $0.82 \mathrm{wt} \%$ and a lower $\mathrm{Al}_{2} \mathrm{O}_{3}: \mathrm{SiO}_{2}$ ratio. Because of the small size, this occurrence is of no practical value (Sborshchikov and others, 1973).

The Tala Barfak (Nalag) occurrence is not recommended for further investigation based on the low percentage of $\mathrm{Al}_{2} \mathrm{O}_{3}$. However, it can serve as an indication of finding more occurences of higher quality. The suggested areas for further work are (1) areas adjacent to the confluence of Ashraf River south bank of Surkhob River to the northeast from Tala Wa Barfak village, (2) in the basin of Geryrud River, and (3) the area along both sides of Surkhob River in the area of of Kaushandos-IshpushtaGaran (Sborshchikov and others, 1973). 


\section{Estoma Bauxite Occurrence}

The Estoma bauxite occurrence (Sborshchikov and others, 1973; 35²6'08" N., 68¹1'16" E.; fig. 18) is at the mouth of the Estoma River, which is the north tributary of Surkhob River in Baghlan Province. The bauxite deposits are at the base of Jurassic coal-bearing deposits. Bauxites compose four layers, which are 2 to $4 \mathrm{~m}$ thick and as much as $70 \mathrm{~m}$ long. The bauxite is gray and light pink and contains fine pisolites. The pisolites have the following chemical content: $\mathrm{Al}_{2} \mathrm{O}_{3}, 52.34$ wt $\%$, and $\mathrm{SiO}_{2}$, $19.95 \mathrm{wt} \%$. The paleosol is approximately 20 to $25 \mathrm{~m}$ thick. The weathered paleosol is widespread on top of the volcanics.

The paleosol was trenched at two intersections over $2 \mathrm{~km}$ apart and channel sampled (fig. 18). The section of the trenches from bottom to top follows (Sborshchikov and others, 1973):

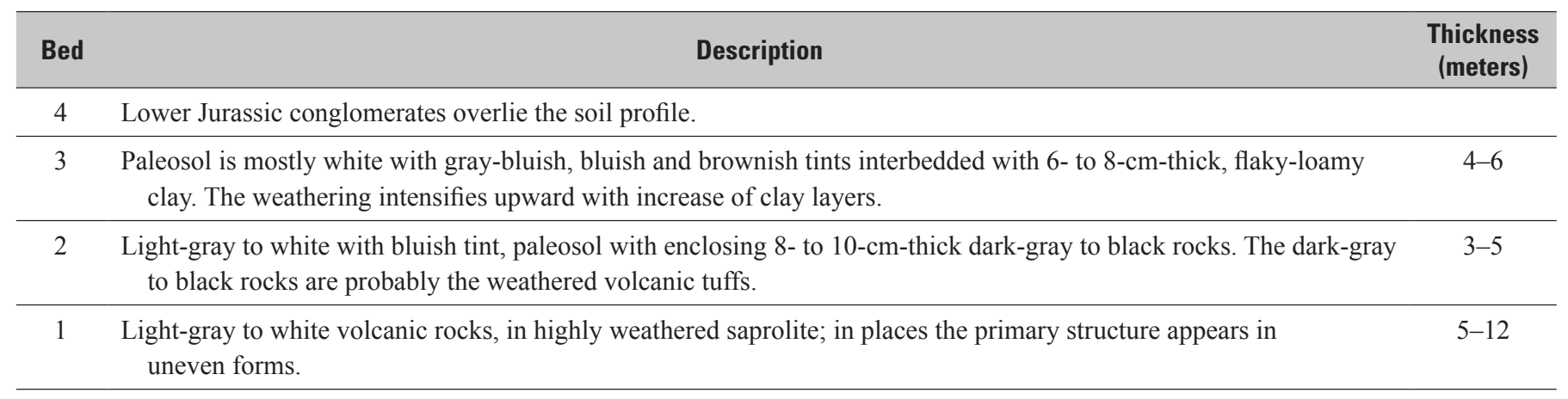

The chemical analyses of channel samples that were collected from the weathered crust are listed in table 10 . A high concentration of alumina was not identified in the sampled rocks.

Table 10. Geochemical results from Estoma bauxite occurrence (Sborshchikov and others, 1973).

[ID, identifier]

\begin{tabular}{|c|c|c|c|c|c|c|}
\hline \multirow{2}{*}{ Number } & \multirow{2}{*}{ Sample ID } & \multicolumn{5}{|c|}{ Content, in weight percent } \\
\hline & & $\mathrm{SiO}_{2}$ & $\mathrm{Al}_{2} \mathrm{O}_{3}$ & $\mathrm{CaO}$ & $\mathrm{MgO}$ & $\mathbf{S}$ \\
\hline 1 & 52 & 62.26 & 13.38 & 2.68 & 0.42 & 0.30 \\
\hline 3 & 54 & 60.16 & 14.69 & 0.78 & 2.10 & 0.35 \\
\hline 4 & 55 & 40.64 & 10.62 & 15.82 & 8.42 & 0.14 \\
\hline 6 & 57 & 60.17 & 13.71 & 1.85 & 1.35 & 0.17 \\
\hline 7 & 58 & 58.81 & 15.56 & 2.55 & 0.45 & 0.28 \\
\hline 8 & 59 & 64.54 & 12.88 & 2.52 & 0.39 & 0.39 \\
\hline 9 & 60 & 62.90 & 12.13 & 4.02 & 0.87 & 0.18 \\
\hline 10 & 61 & 63.90 & 11.35 & 4.27 & 0.63 & 0.11 \\
\hline 14 & 65 & 63.71 & 12.32 & 3.90 & 0.37 & 0.15 \\
\hline 15 & 66 & 65.45 & 13.05 & 3.04 & 0.18 & 0.03 \\
\hline 16 & 67 & 63.13 & 11.73 & 4.62 & 0.39 & 0.06 \\
\hline 17 & 68 & 63.80 & 12.97 & 3.92 & 0.22 & 0.06 \\
\hline 18 & 69 & 65.43 & 12.82 & 3.62 & 0.36 & 0.06 \\
\hline
\end{tabular}




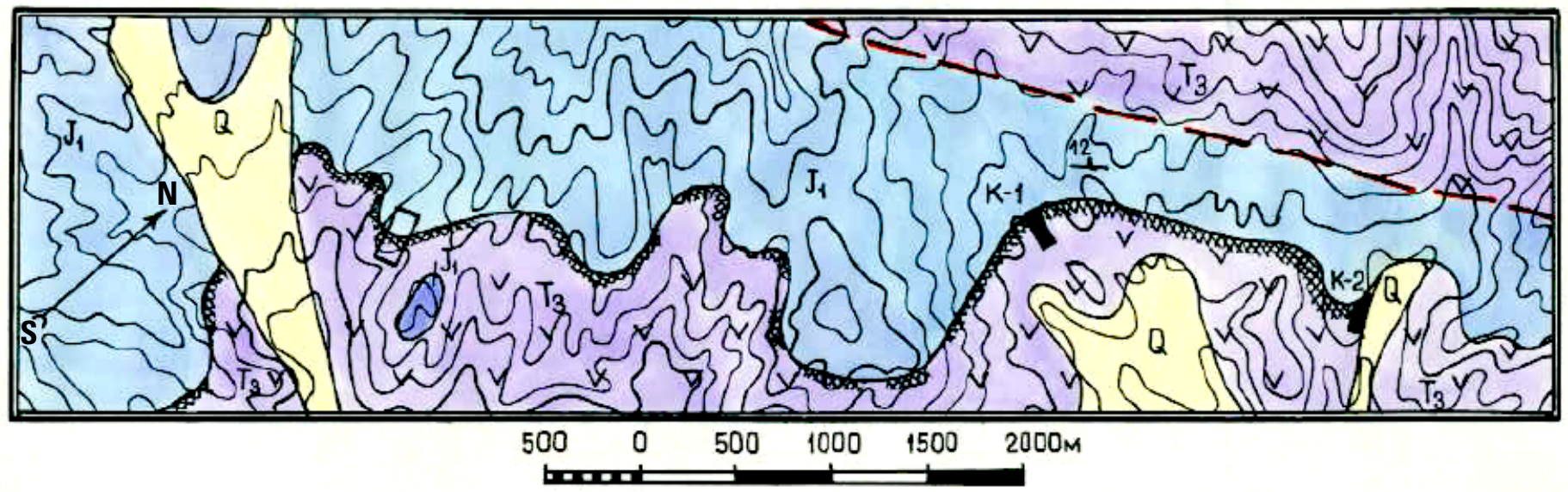

EXPLANATION
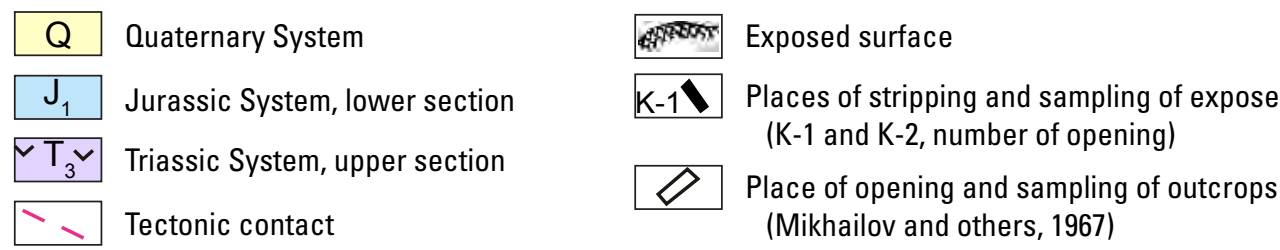

Figure 18. Schematic geologic map of the Estoma bauxite occurrence (Mikhailov and others, 1967).

\section{Eshpushta Bauxite Occurrence}

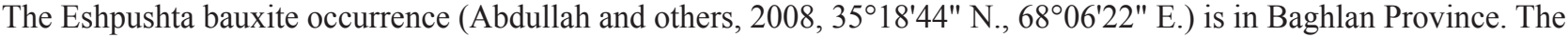
bauxite occurs at the top of a paleosol developed on an erosion surface on top of Upper Triassic volcanic rocks. It occurs as a layer 300 to $400 \mathrm{~m}$ long and 1 to $3 \mathrm{~m}$ thick. The bauxites are light gray and pink and contain small pisolites (Salah and others, 1977), very similar to those in the Estoma occurrence. 


\section{Summary}

Table 11 summarizes the previous discussions of locations, types, and quality of the bauxite occurrences and deposits that were compiled and analyzed in this report. The known resources of bauxite-bearing rocks are widespread in Afghanistan: the possibility of high grade bauxite deposits is low. There may be undiscovered bauxite-bearing rocks. Future exploration for mineral resources in Afghanistan may help to identify additional undiscovered bauxite-bearing deposits of economic value.

Table 11. Summary characteristics of selected bauxite occurrences and deposits in Afghanistan.

$[-$, unknown $]$

\begin{tabular}{|c|c|c|c|c|c|c|c|c|}
\hline Name & Province & $\begin{array}{l}\text { Structural } \\
\text { zone }\end{array}$ & Age & Formation & $\begin{array}{c}\text { Occurrence/ } \\
\text { deposit }\end{array}$ & $\begin{array}{c}\text { Reserves } \\
\text { (million } \\
\text { tons) }\end{array}$ & $\begin{array}{c}\text { Geo- } \\
\text { chemistry } \\
\text { data } \\
\text { available? }\end{array}$ & $\begin{array}{c}\text { Grade } \\
\text { ( } \mathrm{Al}_{2} \mathrm{O}_{3} \\
\text { content, } \\
\text { in weight } \\
\text { percent) }\end{array}$ \\
\hline Kohe-Safed & Ghor & Haftkala & Upper Permian & Pamir & Occurrence & - & Yes & $<50$ \\
\hline Tanura-II & Ghor & Haftkala & Triassic & Limestone & Occurrence & - & Yes & $<50$ \\
\hline Qarghanaw & Ghor & Qarghanaw & Triassic & Dolomite & Occurrence & - & No & - \\
\hline Shewa & Badakshan & North Pamir & Lower Permian & Dolomite & Occurrence & - & No & - \\
\hline Char-Qala & Ghazni & Arghandab & Lower Permian & - & Occurrence & - & Yes & $<50$ \\
\hline Turghan & Zabul & Arghandab & Permian & Chohan & Occurrence & - & No & - \\
\hline Obatu Sheila I & Kandahar & Arghandab & Jurassic & Vargach & Deposit & 7.247 & Yes & $<50$ \\
\hline Obatu Sheila II & Kandahar & Arghandab & Jurassic & Vargach & Deposit & - & Yes & $<50$ \\
\hline Obatu Sheila III & Kandahar & Arghandab & Jurassic & Vargach & Deposit & - & Yes & $<50$ \\
\hline Surkhbet I & Kandahar & Tirin & Jurassic & Vargach & Occurrence & - & Yes & $<35$ \\
\hline Surkhbet II & Kandahar & Tirin & Jurassic & Vargach & Occurrence & - & Yes & $<40$ \\
\hline Zamto-Kalay & Kandahar & Arghandab & Jurassic & Vargach & Occurrence & - & No & - \\
\hline Tor Ghar & Kandahar & Arghandab & Jurassic & Vargach & Occurrence & - & Yes & - \\
\hline Archa Ghar & Kandahar & Arghandab & Jurassic & Vargach & Occurrence & - & Yes & $<25$ \\
\hline
\end{tabular}




\section{References Cited}

Abdullah, S.H., Chmyriov, V.M., and Dronov, V.I., 2008, Geology and mineral resources of Afghanistan—Book 1, Geology: British Geological Survey, Report Series, 488 p.

Bárdossy, G., and Aleva, G.J.J., 1990, Lateritic bauxites: Elsevier, Developments in Economic Geology 27, 624 p.

Blakey, Ron, 2011, Late Permian, Middle Triassic, Early Jurassic global paleogeography: Colorado Plateau Geosystems, Inc., accessed February 5, 2013, at http://cpgeosystems.com.

Chmyriov, V.M., Dronov, V.I., Stazhilo-Alekseev, K.F., Kafarsky, A.Kh., Malyarov, E.P., and Sborshikov, I.M., 1977, The geology and minerals of Afghanistan: Kabul, Afghanistan, Afghanistan Geological Survey Report 1145, v. 1, 245 p.

Cox, D.P., and Singer, D.A., eds., 1986, Mineral deposit models: U.S. Geological Survey Bulletin 1693, 379 p.

Dovgal, Yu.M., Chalyan, M.A., Nagaliov, V.S., Diomin, A.N., Vaulin, V.A., Belitch, A.I., Sonin, I.I., Kononykhin, E.T., Zharikhin, K.G., Maksimov, N.P., Skvortsov, N.S., and Kharitonov, A.P., 1971, The geological structure and mineral resources of the south-eastern part of Central Afghanistan-Report on the results of prospecting and survey operations (scale 1:200,000) carried out in 1967-1970, v. 5: Kabul, Rec. Off., Department of Geological and Mineral Survey.

Dronov, V.I., ed., 1980, Geology and mineral resources of Afghanistan, v. 1, Geology: Moscow, Publishing Office "Nedra," $535 \mathrm{p}$.

Dronov, V.I., Kalimulin, S.M., Kabakov, O.N., Kotchetkov, A.Ya., Zelensky, E.D., Chistyakov, A.N., and Svezhentsov, V.P., 1970, Geological structure and mineral resources of western part of the central Afghanistan (Preliminary report of the Herat group for year 1969): Kabul, Rec. Off., Department of Geological and Mineral Survey.

Dronov, V.I., Kalimulin, S.M., Sborshchikov, I.M., Svezhentsov, V.P., Chistyakov, A.N., Zelensky, E.D., and Cherepov P.G., 1972, Geological structure and mineral resources of the North Afghanistan (parts of map sheets 400-II and 500-I, between Kaysar and Hari Rod rivers): Kabul, Rec. Off., Department of Geological and Mineral Survey.

Dronov, V.I., Leven, E.Ya., and Feruz, N.M., 1975, The Permian deposits of the Afghan Central Badakhshan: Thes. Rep. V knige: III Nauchno-metodicheskaya konferentsiya, KU i KPI, Kabul, p. 62-64.

Dronov, V.I., Leven, E.Ya., and Kalimulin, S.M., 1976, The Permian deposits of the Eaftkala River basin (Middle Afghanistan): V knige: Geologiya i poleznye iskopaemye stran Asii, Afriki I Latinskoi Ameriki. M., Idz.Universiteta d.ruzhby narodov.

Dronov, V.I., Stazhilo-Alekseev, K.F., Kotchetkov, A.Ya., Karapetov, S.S., Kalimulin, S.M., and Sonin, I.I., 1973, The geology and minerals of central and south-western Afghanistan: Kabul, Rec. Off., Department of Geological and Mineral Survey.

Han, Ali Gulyam, 1964, Act: Afghanistan Geological Survey Report R1270, May 25, 9 p.

Jensen, M.L., and Bateman, A.M., 1981, Economic mineral deposits (3d rev. ed.): New York, John Wiley and Sons, 593 p.

Karapetov, S.S., Semionov, Yu.G., and Kotchetkov, A.Ya. , 1969, Geology of central Afghanistan (Part of sheets 500-I, III)Report by the Helmand Team on the 1:500,000 survey in 1968: Kabul, Rec. Off., Department of Geological and Mineral Survey.

Karapetov, S.S., Stazhilo-Alekseev, K.F., Kotchetkov, A.Ya., Seminov, Yu.G., and Gorelov, A.I. 1970, Geology and minerals in the eastern part of Afghanistan-Report of the Helmand Team on the work in 1968-1969: Kabul, Rec. Off., Department of Geological and Mineral Survey.

Lapparent, Albert F. de, 1969, Bauxites of Afghanistan: Kabul, Rec.Off., Department of Geological and Mineral Survey.

Leven, E.Ja., 1976, The Permian deposits of Afghanistan: Byulleten' Moskovskogo obshchestra Ispytateleipireda, Qtd. Geologicheskii, v. 50, no. 5, p. 8-27.

Leven, E.Ja., 1997, Permian stratigraphy and Fusulinida of Afghanistan with their paleogeographic and paleotectonic implications (Stevens, C.H., and Baars, D.L., eds., Shalashilina, T.Yu., translator): Boulder, Colo., Geological Society of America Special Paper 316, 134 p. 
Mikhailov, K.Ya., Kolchanov, V.P., Kulakov, V.V., Pashkov, B.P., Androsov, B.N., and Chalyan, M.A., 1967, Report on geological survey at a scale of 1:200,000 carried out within coal-bearing areas of North-East Afghanistan: Kabul, Rec. Off., Department of Geological and Mineral Survey.

Mikhailov, K.Ya., Kulakov, V.V., Kolchanov, V.P., and Pashkov, B.P., 1965, Report on geological survey of coal deposits and occurrences at a scale of 1:200,000 carried out in the Heart (Hirat) Province: Kabul, Rec. Off., Department of Geological and Mineral Survey.

Mikhailov, K.Ya., Moraliov, V.M., Perfiliev, Yu.S., and Chalian, M.A., 1969, The bauxite potential of the Mezosoic deposits in the southern part of the Afghano-Tadjik Deppression: Razvedka i okhrana nedr, no. 7.

Patterson, S.H., and Dyni, J.R., 1973, Aluminum and bauxite, in Brobst, D.A., and Pratt, W.P., eds., United States mineral resources: U.S. Geological Survey Professional Paper 820, p. 35-43.

Patterson, S.H., 1967a, Descriptive model of laterite type bauxite deposits, in Cox, D.P., and Singer, D.A., eds., Mineral deposit models: U.S. Geological Survey Bulletin 1693, p. 255-258.

Patterson, S.H., 1967b, Descriptive model of karst type bauxite deposits, in Cox, D.P., and Singer, D.A., eds., Mineral deposit models: U.S. Geological Survey Bulletin 1693, p. 258-269.

Patterson, S.H., 1984, Bauxite and nonbauxite aluminum resources and production—An update, in Leonard, Jacob, Jr., ed., Bauxite: U.S. Geological Survey, Reston, Va., p. 3-30.

Peters, S.G., Ludington, S.D., Orris, G.J., Sutphin, D.M., Bliss, J.D., and Rytuba, J.J., eds., 2007, Preliminary non-fuel mineral resource assessment of Afghanistan: U.S. Geological Survey Open-File Report 2007-1214, 810 p.

Retallack, Gregory, 2010, Lateritization and bauxitization events: Economic Geology, v. 105, p. 655-657.

Salah, A.S., Chmyriov, V.M., Abdullah, K.F., Stazhilo-Alekseev, K.F., Azimi, N.A., Dronov, V.I., Gannon, P.J., Rossovskiy, L.N., and Kafarsky, A.Kh., 1977, Mineral resources of Afghanistan: Kabul, Rec. Off., Department of Geological and Mineral Survey.

Sborshchikov, I.M., Loginov, G.S., Dronov, V.I., Bilan, I.K., Cherepov, P.G., and Cherkesov, O.V., 1973, Geological structure and mineral resources of northern Afghanistan (parts of sheets 200 II, III, IV, 500 I): Kabul, Rec. Off., Department of Geological and Mineral Survey.

Siehl, A., 1967, Zur Stratigraphie und Palaeogeographie des Perm in Afghanistan, Translated Title: The stratigraphy and paleogeography of the Permian of Afghanistan: Geologische Rundschau, v. 56, no. 3, p. 795-812.

Tutubalin B.I., Dykul, B.G., Shefa, F.A., Aslam, M.N., Faze, F.A., Lyalgul, V.A., Orlov, V.G., Kudus, A., Tamverk, Yu.S., and Yurgensen, G.A., 1979, Geological structure and mineral resources of the left side of the Gerirud River: Kabul, Rec. Off., Department of Geological and Mineral Survey. 
